UNIVERSIDADE DE SÃO PAULO

FACULDADE DE ECONOMIA, ADMINISTRAÇÃO E CONTABILIDADE MESTRADO PROFISSIONAL EM EMPREENDEDORISMO

FABRICIO ZANELLA DE BORTOLI

Critérios relevantes para a inserção de empresas estrangeiras no Brasil 
Prof. Dr. Vahan Agopyan

Reitor da Universidade de São Paulo

Prof. Dr. Adalberto Américo Fischmann

Diretor da Faculdade de Economia, Administração e Contabilidade

Prof. Dr. Moacir de Miranda Oliveira Jr.

Chefe do Departamento de Administração

Prof. Dr. Marcelo Caldeira Pedroso

Coordenador do Programa de Mestrado Profissional em Empreendedorismo 
FABRICIO ZANELLA DE BORTOLI

\section{Critérios relevantes para a inserção de empresas estrangeiras no Brasil}

Dissertação apresentada ao Programa de Mestrado Profissional em Empreendedorismo do Departamento de Administração da Faculdade de Economia, Administração e Contabilidade da Universidade de São Paulo, como requisito parcial para a obtenção do título de Mestre em Ciências.

Orientador: Prof. Dr. Martinho Isnard Ribeiro de Almeida

Versão Corrigida

São Paulo

2018 


\section{FICHA CATALOGRÁFICA}

Elaborada por Rafael Mielli Rodrigues - CRB-8/7286

Seção de Processamento Técnico do SBD/FEA/USP

De Bortoli, Fabrício Zanella

Critérios relevantes para a inserção de empresas estrangeiras no Brasil / Fabrício Zanella De Bortoli - São Paulo, 2018.

$81 \mathrm{p}$.

Dissertação (Mestrado) - Universidade de São Paulo, 2018.

Orientador: Martinho Isnard Ribeiro de Almeida.

1. Internacionalização de empresas 2. Modos de entrada 3. Empresas entrantes - Brasil 4. Expansão internacional I. Universidade de São Paulo. Faculdade de Economia, Administração e Contabilidade. II. Título.

CDD - 658.049 
À minha esposa Fernanda e aos meus filhos queridos, Fabrício e Larissa, que fazem parte desta conquista.

Aos meus pais Adelino e Mirna, pelos valores transmitidos ao longo da minha vida.

À minha irmã, Camila, que me serve de exemplo para enfrentar os obstáculos mais difíceis. 


\section{AGRADECIMENTOS}

A Deus, por ter me proporcionado a dádiva de ser o pai do Fabrício e da Larissa, crianças que transbordam alegria em suas simplicidades, me mostrando, em momentos difíceis, que a vida é maravilhosa.

À minha esposa, que me apoiou em todos os momentos, inclusive aos fins de semana, ficando sozinha com os nossos filhos, me isentando da fuga aos prazeres cotidianos, para, assim, me dedicar a este trabalho.

À minha mãe, que sempre soube me motivar com palavras certas, em momentos certos, para que eu não desistisse. Ao meu pai, além de melhor amigo, professor doutor em pequenas empresas e com anos de experiência em orientações de trabalhos acadêmicos, que não eximiu esforços e muito me auxiliou em diversas noites após suas duras jornadas de trabalho.

Ao meu orientador, Prof. Dr. Martinho Isnard Ribeiro de Almeida, por ter me guiado com sua experiência, dedicando seu tempo e conhecimento para me mostrar os melhores caminhos e, assim, me proporcionando a base e a tranquilidade para concluir esta dissertação.

Às professoras participantes da banca de qualificação e avaliação final, Prof. ${ }^{a}$ Dra. Patrícia Viveiros de Castro Krakauer e à Prof. ${ }^{a}$ Dra. Heidy Ramos, pelas orientações e à dedicação voluntária que foram imprescindíveis ao conhecimento usado nesta pesquisa.

Aos profissionais consultores especialistas em internacionalização de empresas e aos funcionários das entidades de apoio, que contribuíram com conhecimento e dedicaram tempo para que esta pesquisa alcançasse o seu objetivo. 


\section{RESUMO}

Este trabalho teve como foco principal o estudo dos processos de entrada de empresas estrangeiras no Brasil com o objetivo de responder à seguinte questão de pesquisa: Como auxiliar às empresas internacionais interessadas em se estabelecer no Brasil? Para responder à pergunta acima, o objetivo principal do trabalho foi propor um modelo de fluxo de ações e cuidados a serem tomados para que o dirigente executivo da empresa estrangeira possa se basear e assim, melhor se preparar para a execução de um plano de entrada no mercado brasileiro. A estrutura teórica utilizada para dar apoio ao estudo está dividia em três grupos: As teorias de internacionalização, mostrando a sua evolução no tempo. O segundo grupo descreve os principais modos de entrada de uma empresa em outro país, destacando suas vantagens e características. O terceiro grupo, apresenta as barreiras potencialmente encontradas à entrada de uma empresa em um país estrangeiro. $\mathrm{O}$ método utilizado para o desenvolvimento deste estudo, incluiu, além da pesquisa teórica, o desenvolvimento e aplicação de entrevistas exploratórias com quatro empresas estrangeiras, em que os achados revelaram os modos de entrada utilizados e as razões de escolha de cada uma, bem como as barreiras à entrada e os problemas enfrentados por falta de um plano pré-expansão. A terceira etapa foi constituída de uma abordagem em formato de entrevista com entidades brasileiras de fomento à internacionalização de empresas no Brasil, para entender quais os critérios e processos essas entidades aplicam a suas empresas clientes estrangeiras. Para concluir o método, a quarta etapa foi outra pesquisa, juntamente com um grupo seleto de especialistas consultores em expansão internacional, com o objetivo de validar tais critérios mencionados nas duas pesquisas anteriores. O resultado foi um modelo de fluxo de ações e critérios a serem observados na etapa pré-expansão como a busca por network local, a visita ao país anfitrião de interesse com a participação em rodadas de negócios e desenvolvimento de pesquisa do mercado para o apoio em informações que servirão à continuidade ou não ao plano de expansão. Em sequência, outros critérios que foram mencionados nas pesquisas foi a listagem das potenciais barreiras à entrada e os modos de entrada com suas vantagens e desvantagens para o mercado e a empresa interessada. Por fim, foi mencionado a importância de preparar o plano de negócio e sua implementação, baseados no tempo e custos de investimento encontrados, seguido da fase de acompanhamento com visitas e auditorias locais. Os achados atenderam ao objetivo desta pesquisa, e podem servir de base de consulta para estudantes e outros especialistas sobre o tema de expansão internacional de empresas no Brasil, além do desenvolvimento de novos estudos comparativos.

Palavras-chave: Internacionalização de empresas. Modos de entrada. Empresas entrantes no Brasil. Expansão internacional. 


\begin{abstract}
This work had as its prime focus the study of the processes for the entrance of foreign companies in Brazil in order to respond to the following research question: How to assist international companies interested in establishing themselves in Brazil? To answer the prior question, the main objective of the work was to propose a flow model of actions and care to be taken, so that the executive officer of the foreign company can be based and thus be better prepared for the execution of a plan of entry in the Brazilian market. The theoretical structure used to support the study is divided into three groups: The theories of internationalization, showing their evolution in time. The second group describes key modes for a company to enter another country highlighting its advantages and characteristics. The third group presents potential barriers against the entering of a company in a foreign country.

The method used for the development of this study included, in addition to the theoretical research, the development and application of exploratory interviews with four foreign companies, where the findings revealed the used entry modes and the reasons for choosing each as well as the barriers to the entry and the problems faced by the lack of a pre-expansion plan. The third stage consisted of an approach in the format of an interview with Brazilian entities promoting the internationalization of companies in Brazil, in order to understand what criteria and processes these entities apply to their foreign client companies. To conclude the method, the fourth step was another research along with a distinct group of experts, consultants in international expansion, with the aim of validating such criteria mentioned in the previous two surveys. The result was a flow model of actions and criteria to be observed in the pre-expansion stage such as the search for local network, a visit to the host country of interest with participation in business rounds and the development of market research for information-based support that will serve to the continuity or not of the expansion plan. In sequence, other criteria that were mentioned in the surveys were a list of potential barriers to the entrance and the modes of entry with their advantages and disadvantages for the market and for the interested company. Finally, it was mentioned the importance of preparing the business plan and its implementation based on time and the investment costs found, followed by the monitoring phase with visits and local audits. The findings met the goal of this research and can serve as a basis of consultation for students and other experts about the subject of international expansion of companies in Brazil as well as the development of new comparative studies.
\end{abstract}

Keywords: Internationalization of companies. Input modes. Inbound companies in Brazil. International expansion. 


\section{LISTA DE ILUSTRAÇÕES}

Figura 1 - Análise de Causa-Efeito: Problemas ocasionados pela falta de planejamento ....... 17

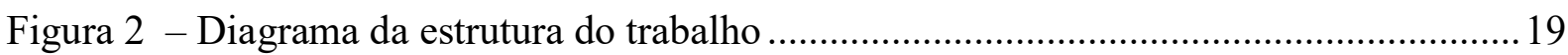

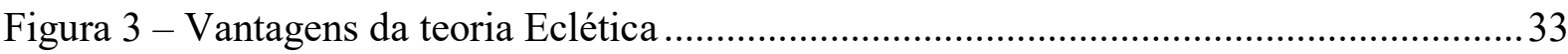

Figura 4 - Critérios apresentados pelas entidades no Brasil de fomento à internacionalização

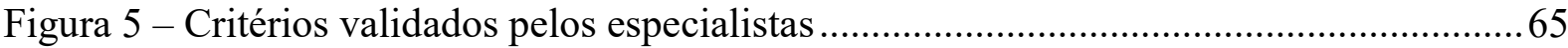

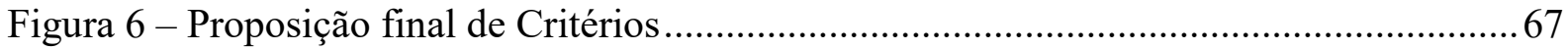

Quadro 1 - Teorias de Internacionalização e modos de entrada ...........................................23

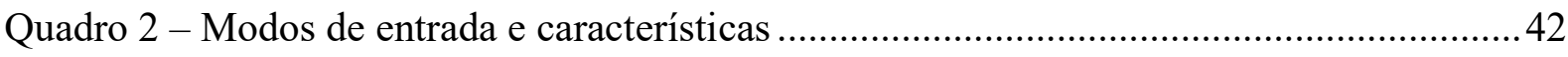

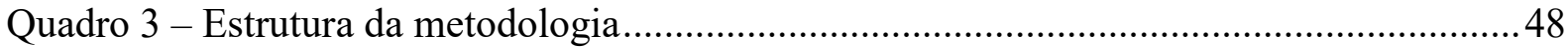

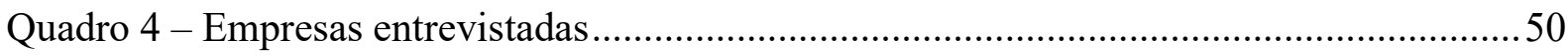

Quadro 5 - Entidades de apoio à internacionalização contatadas no Brasil ...........................51

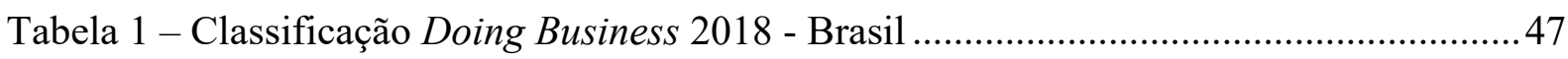

Tabela 2 - Critérios mencionados pelas empresas entrantes no Brasil ....................................62 


\section{SUMÁRIO}

1 INTRODUÇÃ

1.1 Relato da Experiência ..................................................................................................................12

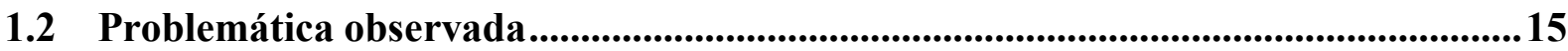

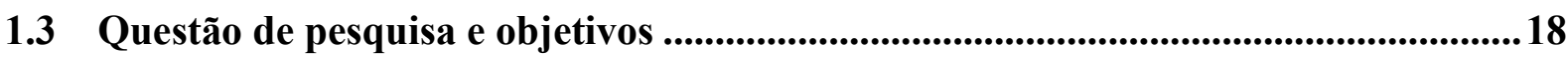

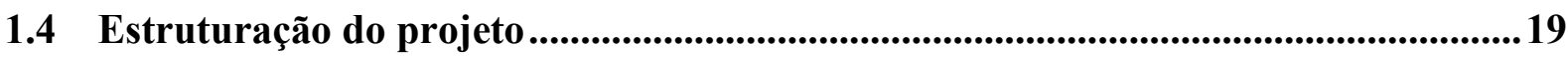

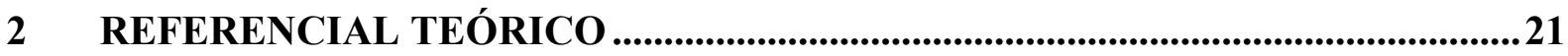

2.1 Teorias da Internacionalização …...................................................................................21

2.1.1 Teoria da Vantagem Monopolista ...................................................................................23

2.1.2 Teoria do Ciclo de Vida do Produto Internacional................................................................25

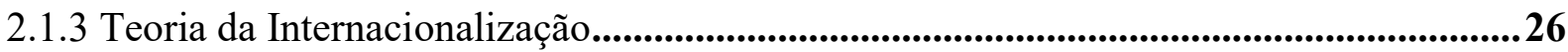

2.1.4 Teoria das Redes..............................................................................................................28

2.1.5 Teoria da Internalização .........................................................................................30

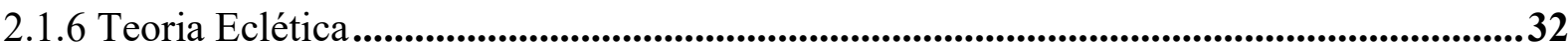

2.1.7 Teoria do Custo de Transação ......................................................................................................34

2.1.8 Teoria Baseada em Recursos ......................................................................................36

2.1.9 Teoria da Contingência...............................................................................................38

2.2 Modos de entrada no mercado estrangeiro ................................................................40

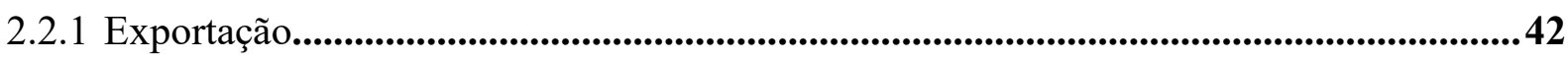

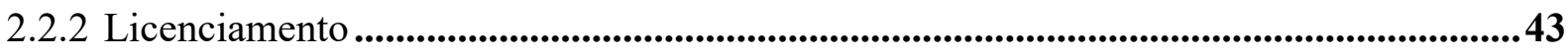

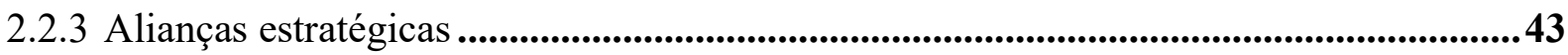

2.2.4 Aquisição ...............................................................................................................................................44

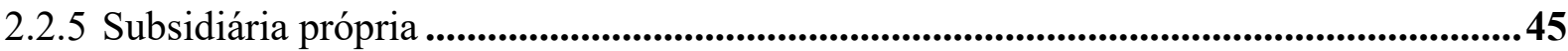

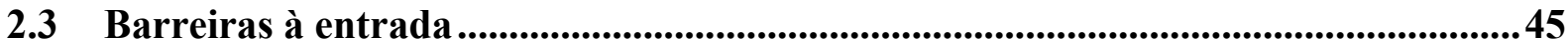

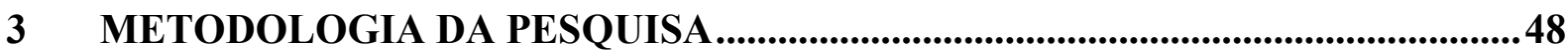

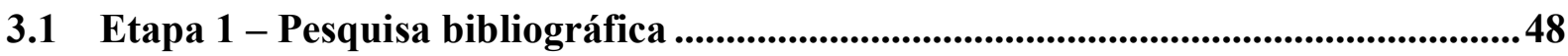

3.2 Etapa 2 - Pesquisa exploratória qualitativa ...................................................................49

3.3 Etapa 3 - Pesquisa com entidades de apoio à internacionalização ............................50

3.4 Etapa 4 - Pesquisa com especialistas no processo de entrada no Brasil ...................51

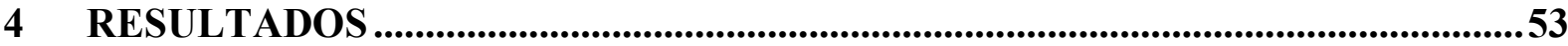

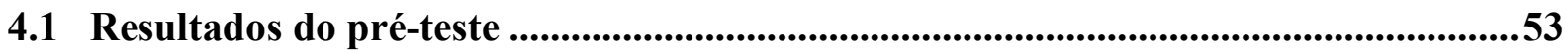

4.2 Resultados da pesquisa exploratória: empresas ....................................................55 
4.3 Resultados da pesquisa com entidades de apoio à internacionalização.....................60

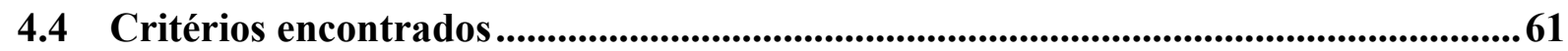

4.5 Validação dos critérios encontrados .................................................................64

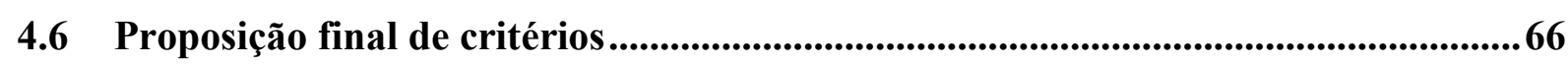

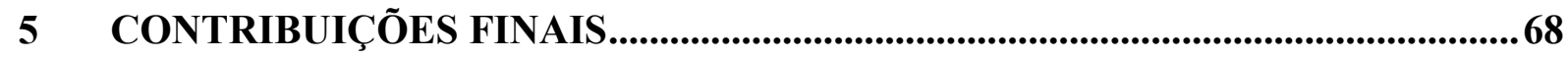

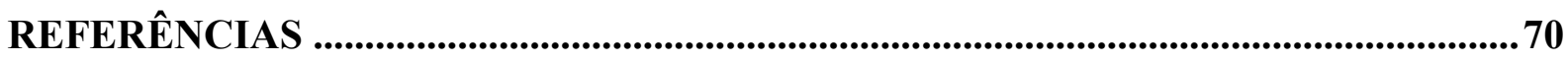

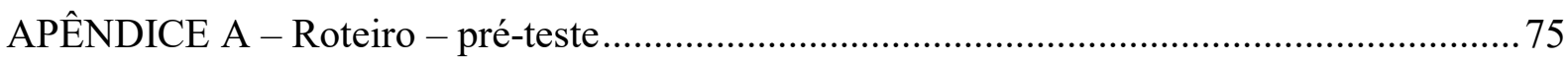

APÊNDICE B - Roteiro empresas entrantes ..................................................................... 77

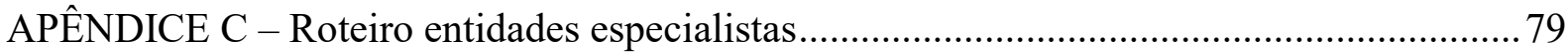

APÊNDICE D - Lista de especialistas brasileiros em internacionalização ............................. 81 


\section{INTRODUÇÃO}

A globalização da economia foi um marco sem volta para empresas do mundo todo se internacionalizarem. Na busca de expansão comercial, com o intuito de aumentarem a economia de escala de produção e aumento da participação, as empresas passaram a se dedicar cada vez mais na internacionalização aos mercados chamados de emergentes.

Para muitos autores de diversos estudos de negócios internacionais, a internacionalização das empresas é um processo gradual de aumentar o seu envolvimento internacional. No âmbito dos fatores econômicos e empresariais, as características deste processo influenciam o padrão e o ritmo de internacionalização destas empresas (JOHANSON; VAHLNE, 1977).

Para o estudo de Khanna, Palepu e Sinha (2005), o fato de muitas corporações entrarem em novas terras é devido a experiências pessoais dos gerentes sêniores, a laços familiares, por seguirem alguns clientes-chave ou simplesmente por sentimentos de que o resultado será positivo. Para Sakarya, Eckman e Hyllegard (2007), destaca-se, ainda, a maneira como é analisada a seleção de um mercado emergente ao se considerar uma expansão internacional, se essa for baseada apenas em fatores macroeconômicos e políticos, desconsiderando o seu dinamismo e o real potencial futuro.

Durante a decisão do processo de expansão internacional, as empresas deveriam ter uma estratégia para escolherem os mercados e o momento mais favorável, além de melhor definirem qual o melhor modelo de entrada nestes mercados (EKELEDO; SIVAKUMAR, 2004; KUMAR; SUBRAMANIAM, 1997).

O pesquisador deste estudo investigou quatro diferentes processos de introdução de empresas no Brasil, fabricantes de equipamentos e consumíveis diversos, nos quais o principal ponto em comum, e o que o levou, inclusive, ao desenvolvimento deste trabalho, foi a falta de um método nas empresas que funcionasse como diretriz no processo de introdução no mercado brasileiro. Como constatado em entrevistas, as matrizes das empresas e seus executivos desconheciam e/ou ignoraram peculiaridades do mercado brasileiro, como, por exemplo, a elevada burocracia 
nos processos, a alta carga tributária, entre outros fatores, e não se dedicaram em estudar as principais opções de modelos de entrada versus o tempo desejado de retorno, tomando decisões sem embasamento. Isso gerou, segundo relatado, custos de estrutura e pessoal desnecessários, além de prazos estipulados pela matriz quase sempre inalcançados.

O pesquisador identificou, portanto, um ambiente de incerteza que as empresas enfrentaram por não pré-determinarem um plano para a introdução no mercado brasileiro. Por outro lado, a literatura destaca diferentes processos de internacionalização e suas características, paralelamente aos modos de entrada no estrangeiro. Nesse sentido foi formulada a questão de pesquisa "Quais critérios de entrada devem ser considerados pelas empresas interessadas em se estabelecer no Brasil?" Dado isto, o presente trabalho tem como objetivo principal de, baseado nas teorias de internacionalização e seus fatores potenciais de sucesso para cada modelo de escolha de expansão, mostrar aos dirigentes, tomadores de decisão das empresas entrantes, quais considerações e práticas devem ser consideradas e relacionadas para o processo de entrada no Brasil.

\subsection{Relato da Experiência}

Nos últimos 16 anos, o pesquisador do presente estudo atuou no processo da introdução e desenvolvimento de quatro distintas empresas estrangeiras no Brasil, sendo que em três delas atuou como gerente de vendas e marketing na América Latina, e na quarta empresa como consultor autônomo.

Estas empresas possuem nacionalidades distintas, sendo uma canadense, duas italianas e uma indiana. Todas atuam no ramo da saúde, fabricantes de equipamentos, acessórios e consumíveis para diferentes especialidades médicas.

A primeira experiência, denominada de "Paris", se trata de uma empresa francesa, com 800 funcionários no mundo, fabricante de utensílios e materiais escolares como réguas, compassos, borrachas, tesouras e outros. A empresa iniciou sua entrada no Brasil com o modelo da abertura 
de uma subsidiária e, nos primeiros meses, utilizou-se da estrutura física do escritório de contabilidade, prestador de serviços administrativos e contábeis.

O início das atividades no Brasil deu-se com a contratação de agentes comerciais autônomos, terceirizados, que conheciam o setor, porém, nunca tinham atuado com o alto padrão de qualidade e design dos produtos, além do preço maior em relação aos competidores já estabelecidos no Brasil. Contratado com o cargo de coordenador comercial, o autor desta dissertação solicitou à matriz algum estudo de mercado realizado para a decisão de vinda ao mercado brasileiro. Para sua surpresa, este estudo não existia, ou seja, a decisão de expansão no Brasil foi tomada sem ter conhecimento do real tamanho da oportunidade. Ele próprio acabou por iniciar um estudo de dimensionamento e levantamento dos players (concorrentes, preços, potenciais clientes), ao longo do processo de introdução da empresa.

Outro ponto que os dirigentes não contavam foi com o alto preço que o produto nacionalizado alcançou. A matriz se surpreendeu com o preço final que se obteve dos produtos, após o primeiro desembarque realizado. A carga tributária, custo do frete e burocracia alfandegária contribuíram para retardar demasiadamente o lançamento da linha de produtos no Brasil. A empresa teve que custear durante um ano e meio a estrutura de 2 funcionários, o aluguel de um escritório em região nobre da cidade de São Paulo, problemas estes que poderiam ter sido evitados se houvesse um planejamento adequado prévio.

A segunda experiência se trata de uma empresa canadense, denominada "Montreal", de médio porte, com 350 funcionários, fabricante de equipamentos e respectivos insumos para o mercado de urologia, os quais eram utilizados em exames de medição do funcionamento da bexiga. Um ano antes do processo de internacionalização, o fundador e atual CEO da empresa iniciou visitas ao Brasil, visando o levantamento de informações, com o objetivo de conhecer potenciais agentes locais, distribuidores e, deste modo, atuar com alianças estratégicas como modo inicial de entrada no mercado. Durante suas visitas, reconheceu que uma atuação direta e de maior controle seria mais complexa, porém de potenciais retornos mais rápidos. Sendo assim, escolheu o modo de abertura de subsidiária, criando a filial brasileira.

Sem o conhecimento amplo do potencial do mercado, legislação, tributação, o fundador se apoiou em escritório de advogados e de contabilidade para a abertura da empresa e as primeiras 
contratações de pessoas, porém já com a decisão tomada e o processo iniciado. Não demorou para o empresário se surpreender com os altos custos de certificados necessários para a operação, além da morosidade para a obtenção dos registros perante a Agência Nacional de Vigilância Sanitária - Anvisa, o que também impossibilitava a venda e, consequentemente, o faturamento e geração de receita para manter toda a estrutura inicial implantada.

Para o início da operação, o empresário montou um escritório, contratou 5 pessoas, e, devido à falta de licenças, não pôde importar nenhum equipamento durante dois anos. Isso impossibilitou o faturamento e geração de receita versus os custos de toda a estrutura física mantida pela matriz. O início do faturamento estava sujeito à liberação da licença da vigilância sanitária, prazo também dependente da grande fila de solicitações e morosidade da burocracia.

A terceira experiência se trata de uma empresa italiana, denominada "Roma", de médio porte, com mais de 500 funcionários no mundo, fabricante de medicamentos injetáveis utilizados em exames de imagem para o diagnóstico de doenças. A empresa já atuava no mercado através da exportação, por meio de sua principal concorrente, que complementava seu portfólio comprando essa linha de produtos da fabricante, para a venda no Brasil. No momento em que essa concorrente desenvolveu uma linha de produto similar própria, decidiu-se pela rescisão contratual, servindo de impulso na tomada de decisão para a vinda ao mercado brasileiro.

A empresa iniciou sua atuação com a compra de uma empresa de "prateleira" - termo popular usado para denominar empresas que estão legalmente ativas, ou seja, aptas a atuar no mercado da saúde, com seus registros de funcionamento e outros documentos em dia, porém, sem produtos ou serviços para ofertar. O objetivo desta ação era ter uma estrutura mínima para iniciarem os devidos registros sanitários dos produtos em nome próprio e não utilizar de uma empresa hospedeira, pois a transferência, depois, poderia levar mais tempo. Nesta fase o tipo de entrada escolhido foi o da abertura de subsidiária.

Um desafio enfrentado inicialmente, também devido à falta de conhecimento por parte dos executivos italianos, foi o de comercializar os produtos sem o poder, em seu nome, do devido registro perante a Anvisa. Apesar da compra de uma empresa de prateleira que possuía os registros de funcionamento local, os registros de produtos estavam em nome da antiga empresa distribuidora, que passou a ser sua concorrente com outro produto. Sem esses registros, a 
empresa comprou o estoque remanescente de produtos de sua própria marca, do então distribuidor, a um preço muito acima do mercado e em grandes quantidades. Isso levou a empresa a arcar com um grande prejuízo financeiro. Esses problemas de morosidade em conseguir o registro próprio dos produtos, além da compra de estoque com valores acima do preço médio de venda no mercado, não haviam sido considerados num planejamento prévio para a devida entrada da empresa no Brasil.

A quarta experiência se deu com a abertura de uma representante brasileira, aqui a ser chamada de codinome "Angrez", para representar uma fabricante de software indiano, capaz de propiciar o acesso dos médicos especialistas - por um dispositivo móvel como tablets, smartphones e notebooks - às imagens radiológicas dos exames realizados, visando à elaboração e emissão dos laudos para qualquer lugar do mundo, se assim necessário. O modo de entrada neste caso foi o de exportações. A experiência do autor neste caso foi com a participação na empresa representante local. Houve um estudo prévio do mercado potencial, porém superficial, o qual se mostrou positivo através das conversas informais realizadas. Quando disponibilizou-se o produto, os executivos brasileiros enfrentaram a necessidade de colocarem em teste, demandando um tempo maior de venda do que o acordado com a matriz na Índia. Como a empresa nacional foi uma start-up contando com esse único produto, ela fechou suas operações após 1 ano de vida ao constatar que o preço final do produto era incompatível com o praticado pelos concorrentes. A empresa começou alugando e reformando um escritório, contratando também uma secretária e dando início à solicitação dos registros sanitários necessários para sua operação. Durante um ano, a empresa não conseguiu fazer nenhuma venda, pois o preço do produto estava acima do mercado. Com o fechamento da empresa brasileira, a empresa indiana desistiu do mercado brasileiro.

\subsection{Problemática observada}

O autor observou em sua experiência profissional que são diversas as razões e as maneiras pelas quais as empresas estrangeiras ingressam no mercado brasileiro. Muitas entram por aquisição, outras no formato de joint ventures, e, muitas outras, abrindo uma subsidiária própria, 
utilizando-se do apoio de um escritório de advocacia e iniciando a contratação de um executivo, cuja função é de implantar a empresa desde o início.

As empresas em geral preferem entrar em mercados com alto grau de atratividade, baixo risco de mercado e onde podem desfrutar de uma vantagem competitiva. Apesar de classificados como ambientes de alto risco, o mercado emergente demanda maior consideração no desenvolvimento de operações internacionais e oferece um campo de pesquisa para o estudo da seleção de mercado, dentro de um ambiente de mercado global cada vez mais desafiador. A falta de uma abordagem especializada para avaliar o seu potencial pode ser uma das razões pelas quais a maioria das empresas negligencia oportunidades nos mercados emergentes. É importante como é analisada a seleção de um mercado emergente ao se considerar uma expansão internacional, pois, se for baseada apenas em fatores macroeconômicos e políticos, pode desconsiderar o seu dinamismo e o real potencial futuro (SAKARYA; ECKMAN; HYLLEGARD, 2007).

Para CEOs e times gerenciais de empresas, particularmente da América do Norte, Europa e Japão, a última década tem sido muito desafiadora em identificar uma estratégia adequada para a internacionalização. A maioria das empresas mantém o uso de modelos, o que de alguma forma funcionou no passado, porém, encontram altíssimo desafio em obterem sucesso no desenvolvimento em mercados emergentes. Parte desse desafio está ligado à ausência de intermediários, sistemas regulatórios e mecanismos de execução de contratos, chamados de "vazios institucionais" (KHANNA; PALEPU; SINHA, 2005, p.1).

Pela proposta baseada na experiência do pesquisador, estas empresas, ao definirem o mercadoalvo, neste caso, o Brasil, não se baseiam em estudos prévios de viabilidade, potencial de mercado e restrições legais. Sequer foi mencionada a necessidade da realização de um projeto, muito menos o alinhamento do processo, considerando o embasamento e suporte em uma das teorias conhecidas de internacionalização. As decisões eram tomadas reativamente aos fatos e barreiras encontradas ao longo do processo, nunca de forma prevista ou planejada.

A experiência mostrou ao pesquisador a falta de planejamento estratégico prévio, tanto na decisão da expansão quanto ao longo da fase de internacionalização dessas empresas. Ainda consoante sua experiência, é possível verificar que as decisões se basearam no conceito de o 
Brasil ser entendido como um mercado de fácil introdução, com classes sociais ascendentes e com a presença de concorrentes - elementos que aceleraram as decisões de vinda ao país, ainda que sem planejamento pormenorizado.

A fim de extrair da realidade os componentes para a questão da pesquisa, baseada na experiência do autor, aplicou-se a ferramenta de exploração e identificação dos principais problemas, conhecida como Diagrama de Causa-Efeito, desenvolvida por Ishikawa (1993). O resultado segue apresentado na Figura 1:

Figura 1 - Análise de Causa-Efeito: Problemas ocasionados pela falta de planejamento

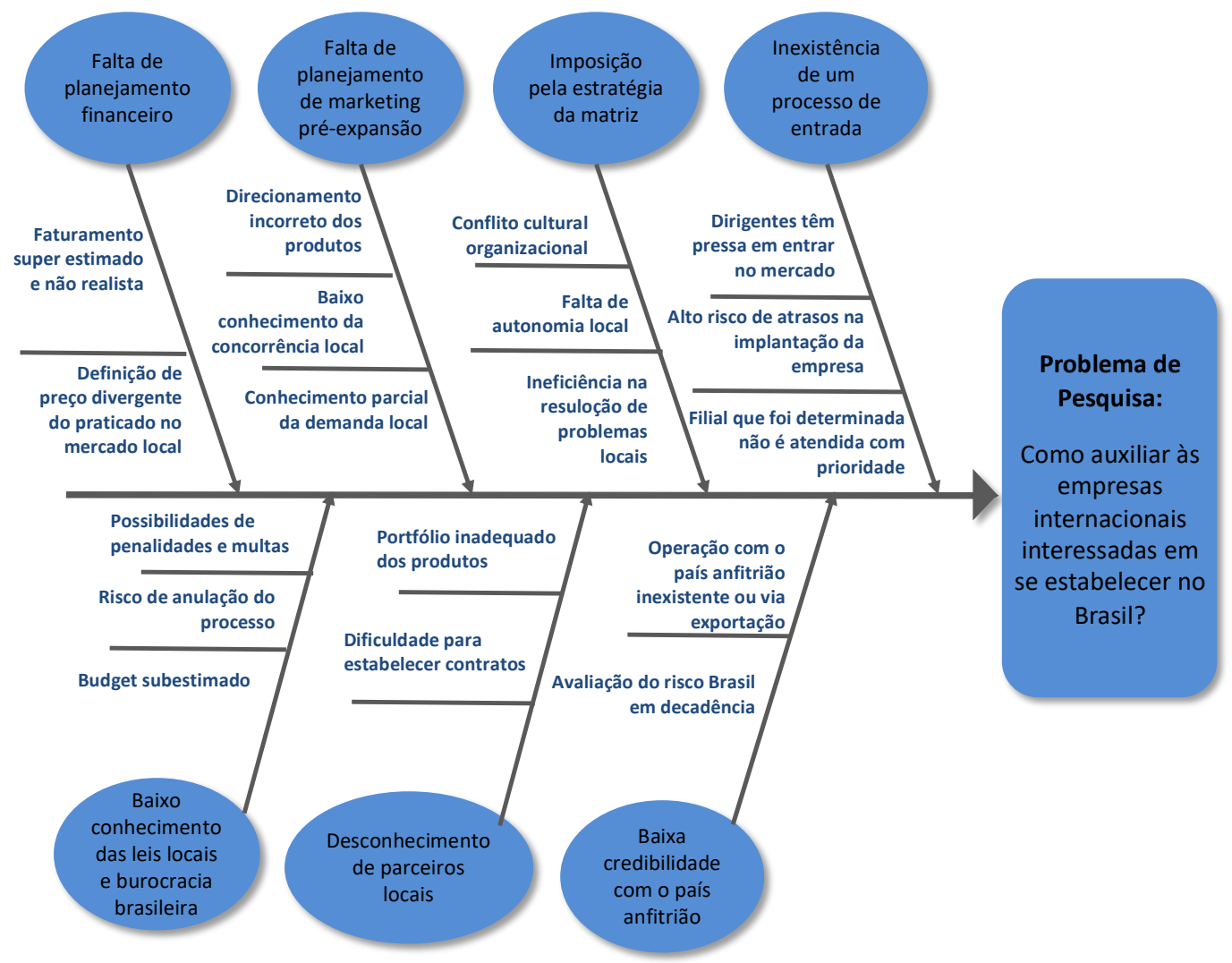

Fonte: Elaborado pelo autor (2018).

É possível constatar, que o início destas expansões vivenciadas pelo pesquisador, se dava com a contratação de um executivo, o qual ficava responsável pela montagem da estrutura da empresa no Brasil. Contudo, tal executivo iniciava suas atividades em busca de responder às seguintes perguntas: "qual o objetivo de vendas no primeiro ano?"; "qual o tempo que a matriz espera alcançar o equilíbrio financeiro?”; “quanto iria precisar de investimento nos próximos 3 anos?"; "qual a linha de produtos está pronta para atender as exigências das normas 
brasileiras?". Todas estas e muitas outras perguntas somente eram respondidas após a execução de pontos que tornaram os negócios custosos, com escritórios superdimensionados, contratação desnecessária de equipe inicial - levando à ociosidade de colaboradores, falta de portfólio de produtos adequados ao mercado local, entre outros problemas que geraram custos desnecessários.

Para o desenvolvimento do presente trabalho, o pesquisador focará nas empresas em que atuou, as quais possuem características similares no que tange ao tamanho, número de funcionários e estruturas globais, tal como já relatado no item "Relato da Experiência".

\subsection{Questão de pesquisa e objetivos}

A proposição deste trabalho é responder à questão: Como auxiliar às empresas internacionais interessadas em se estabelecer no Brasil?

Para responder à questão da pesquisa, teve-se como objetivo principal do trabalho propor um modelo de fluxo de ações e cuidados a serem tomados para que o dirigente executivo da empresa estrangeira possa se basear e assim, melhor se preparar para a execução de um plano de entrada no mercado brasileiro.

No que concerne aos objetivos secundários, que darão sustentação para se alcançar o objetivo principal, tem-se:

- pesquisar empresas entrantes no Brasil, quanto aos desafios e barreiras enfrentados durante o processo de entrada;

- identificar as entidades de fomento à entrada de empresas no Brasil, tais como, consulados, câmaras de comércio e outras, para entender quais critérios utilizam para suportar a entrada das empresas interessadas;

- validar junto a profissionais e consultores especialistas na internacionalização de empresas, os critérios e processos mencionados pelas entidades de fomento e pelos executivos entrevistados. 


\subsection{Estruturação do projeto}

A fim de atingir os objetivos propostos, o trabalho foi estruturado de acordo com a Figura 2, a seguir:

Figura 2 - Diagrama da estrutura do trabalho

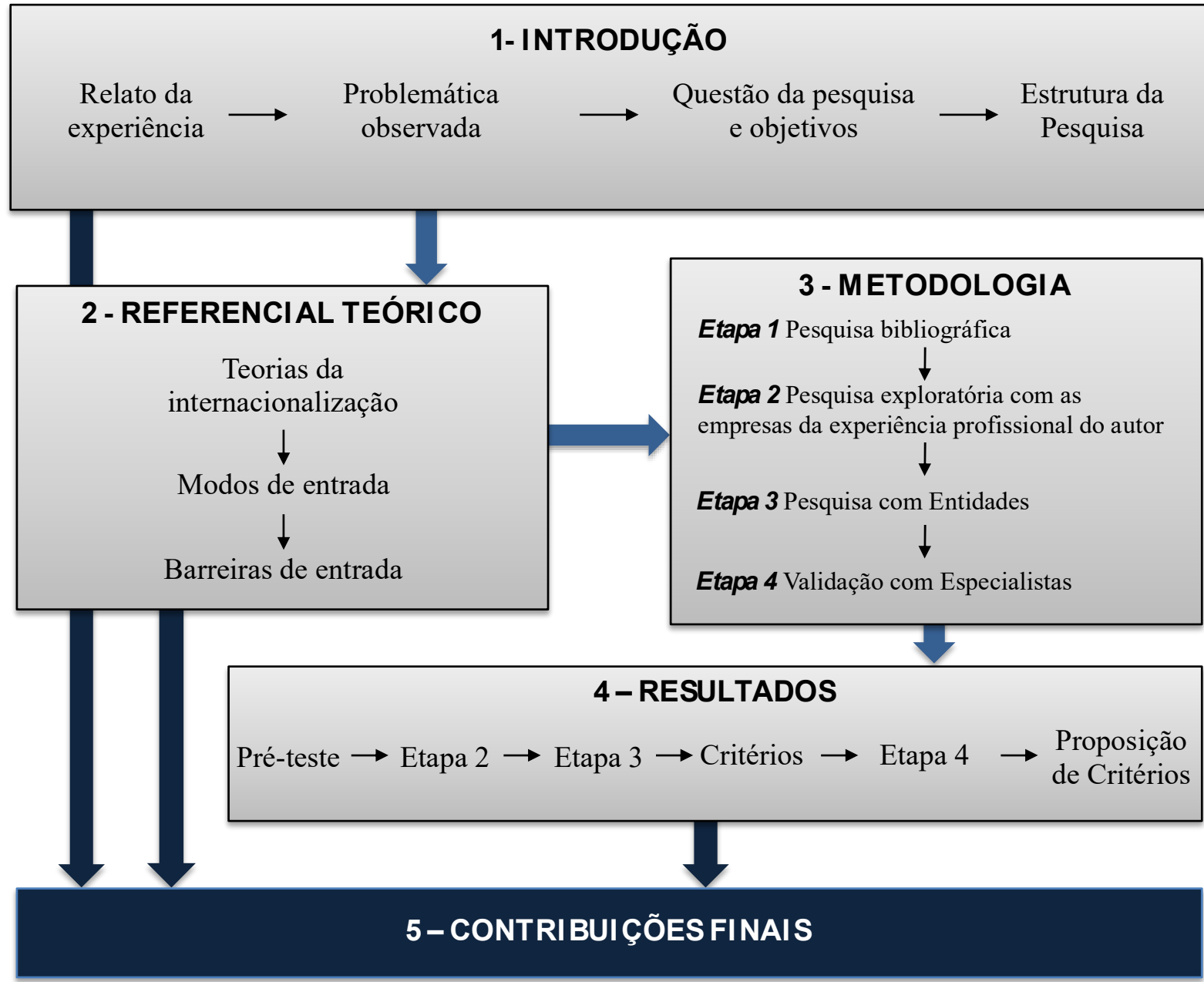

Fonte: Elaborado pelo autor (2018).

O capítulo 1 introduz o leitor ao tema da pesquisa, contextualizando-o e apresentando o relato da experiência do autor em sua participação em diferentes processos de entrada de empresas estrangeiras no Brasil. A partir do relato, descreve-se a problemática observada que serve de ponto inicial para a introdução da questão da pesquisa e seus objetivos, primário e secundários.

O capítulo 2 contém a fundamentação teórica usada para complementar o material que deu suporte e respondeu aos questionamentos do relato da experiência. A teoria é descrita de forma 
cronológica quando mencionam-se as teorias de internacionalização. Isso é relevante para o leitor entender de que forma se desenvolveram tais teorias, seus autores, além dos pontos positivos e falhas de cada uma apontadas por outros autores. Ainda neste capítulo, relatou-se os modos de entrada mais usados por empresas estrangeiras, com o objetivo de explanar suas principais características e diferenças. Por último, mencionam-se as barreiras à entrada mais observadas por empresas estrangeiras durante o processo de expansão em outros mercados.

O capítulo 3 descreve a metodologia e está dividida em 4 etapas:

- Etapa 1 - composta pela pesquisa bibliográfica onde foi realizado o levantamento das teorias existentes da internacionalização, desde o surgimento até as teorias mais atuais.

- Etapa 2 - dividida em entrevista pré-teste onde foi aplicado um questionário semiestruturado em uma empresa somente e em seguida, foi realizada as entrevistas com as empresas nas quais o autor trabalhou.

- Etapa 3 - abrangeu o levantamento de entidades de fomento à entrada de empresas estrangeiras no Brasil e aplicação de entrevista exploratória para o entendimento do processo utilizado entre essas entidades e seus clientes.

- Etapa 4 - etapa desenvolvida com entrevista exploratória com especialistas consultores na área de expansão internacional de empresas, com o objetivo de validar os achados na etapa 3.

O capítulo 4 é composto pelos resultados encontrados em cada etapa mencionada na metodologia. Estes resultados estão divididos e apresentados por etapas, com a inclusão de dois subcapítulos: o primeiro com os critérios sugeridos pelos executivos das empresas entrevistadas e os critérios utilizados pelas entidades de apoio as empresas entrantes e o segundo, resultante da validação pelos especialistas, chamado de proposição final de critérios, apresentado em formato de quadro esquemático.

O capítulo 5 menciona as reflexões do autor sobre o desenvolvimento desta pesquisa, citando os desafios e limitações encontradas com relação à abordagem deste método e outros pontos que poderiam ser relevantes para estudos futuros. 


\section{REFERENCIAL TEÓRICO}

O arcabouço teórico que serve de base para esse estudo está dividido em três partes. As teorias da internacionalização, os modos de entrada num país estrangeiro e as barreiras à entrada mais comumente encontradas pelas empresas que expandem internacionalmente.

A primeira descreve, de forma cronológica, as teorias da internacionalização e sua evolução histórica mencionado as principais bases nas quais seus autores se apoiaram e as relacionaram para explicarem as razões mercadológicas e comportamentais dos dirigentes das empresas no uso dessas teorias. A segunda parte está diretamente ligada à primeira, pois toda teoria de internacionalização menciona a decorrência de sua escolha para um ou mais modo de entrada específico, podendo ocorrer o processo por etapas. A terceira parte, barreiras à entrada, é inerente às empresas que se propõem à internacionalização de suas operações e foi descrita baseada no que foi relatado pelo autor em suas experiências profissionais.

\subsection{Teorias da Internacionalização}

As primeiras teorias de internacionalização foram introduzidas por pesquisadores nas décadas de 1960 e 1970. Em 2004, essas teorias foram agrupadas em 3 paradigmas: paradigma da imperfeição de mercado, entre 1960 e 1970, paradigma comportamental, dominante entre os anos setenta e primeira metade dos anos oitenta, e o paradigma do fracasso de mercado, dominante entre os anos oitenta em diante. Esses três paradigmas representavam uma visão para a empresa de fora para dentro, o que tem contribuído para explicar a diversidade de modos de comercialização de diversos países e, assim, facilitar o entendimento de modelos contratuais, modos de operações estrangeiras, como joint ventures e outros modos de operações. Com o crescimento da literatura nos modos de entrada, essas teorias tiveram um importante avanço a partir da metade dos anos oitenta, dando origem a outras duas teorias: teoria Resource-Based View (RBV), em que a visão da empresa é de dentro para fora, ou seja, a escolha do modo de entrada se baseia nos recursos disponíveis da empresa entrante, e a teoria da contingência, que explica o comportamento internacional das empresas (ERRAMILLI; SHARMA, 2004). 
Seguindo a divisão dos paradigmas, o primeiro, imperfeição de mercado, foi introduzido com a teoria das organizações industriais (OI) por Bain (1956), atribuindo que as indústrias que operam num mercado imperfeito, com poucos competidores e altas barreiras à entrada, esperam retornos financeiros maiores. As imperfeições de mercado podem existir nos mercados gerenciados por produtos (diferenciação de produto, marca e habilidades de marketing), nos mercados gerenciados por fatores (propriedade de tecnologia e habilidades gerenciais), quando incluem a competição imperfeita, causada por políticas e restrições governamentais (fatores tarifários e não tarifários), e ainda a concorrência imperfeita de escala (AGARWAL, MALHOTRA; ULGADO, 2003).

Originado da teoria comportamental de Cyert e March (1963), o paradigma comportamental descreve que a internacionalização é um processo de aprendizado progressivo, gradual e reativo ao conhecimento do mercado por parte dos dirigentes. Supõe-se que a empresa inserida em um mercado imperfeito seja avessa ao risco, sendo isso mais satisfatório do que a maximização do lucro (ERRAMILLI; SHARMA, 2004).

O paradigma da falha do mercado foi originado da evolução da teoria da firma de Coase (1937), em que existem dois modos alternativos de desempenhar uma função econômica, o de mercado e o hierárquico, sendo que a escolha de um desses modos é baseada em sua eficiência relativa. Dentro de uma concorrência perfeita, o modo de mercado é mais eficiente, no entanto, quando o mercado falha, é melhor para a empresa internalizá-lo. Neste paradigma se enquadram as teorias de internacionalização, eclética e custo de transação (ERRAMILLI; SHARMA, 2004).

O Quadro 1 mostra o agrupamento desses paradigmas em nove teorias da internacionalização: 
Quadro 1 - Teorias de Internacionalização e modos de entrada

\begin{tabular}{|c|c|c|c|}
\hline Paradigmas & Teorias & $\begin{array}{c}\text { Descrição da escolha do modo de } \\
\text { entrada }\end{array}$ & Fundador \\
\hline \multirow{2}{*}{$\begin{array}{l}\text { Imperfeição do } \\
\text { mercado }\end{array}$} & $\begin{array}{l}\text { Teoria da Vantagem } \\
\text { Monopolista }\end{array}$ & $\begin{array}{l}\text { Quando a imperfeição do mercado é alta, } \\
\text { prefere-se o IDE. Ao contrário, prefere-se } \\
\text { o licenciamento. }\end{array}$ & Hymer (1960) \\
\hline & $\begin{array}{l}\text { Teoria do Ciclo de Vida } \\
\text { do produto } \\
\text { internacional }\end{array}$ & $\begin{array}{l}\text { Nos primeiros estágios do ciclo do } \\
\text { produto, prefere-se a exportação. Em } \\
\text { estágios avançados, prefere-se o IDE. }\end{array}$ & Vernon (1966) \\
\hline \multirow[t]{2}{*}{ Comportamental } & $\begin{array}{l}\text { Teoria da } \\
\text { Internacionalização }\end{array}$ & $\begin{array}{l}\text { Devido à incerteza do mercado anfitrião, } \\
\text { as empresas adotam modos de entrada } \\
\text { sequenciais, iniciando por exportação } \\
\text { indireta a exportação direta e propriedade } \\
\text { local. }\end{array}$ & $\begin{array}{l}\text { Johanson e } \\
\text { Wiedersheim- } \\
\text { Paul (1975) }\end{array}$ \\
\hline & Teoria das Redes & $\begin{array}{l}\text { Se as relações na rede fornecem fortes } \\
\text { vantagens competitivas, prefere-se o IDE. } \\
\text { Caso contrário, adota-se modos de baixo } \\
\text { controle no país anfitrião. }\end{array}$ & $\begin{array}{l}\text { Håkansson } \\
\text { (1987) }\end{array}$ \\
\hline \multirow{3}{*}{$\begin{array}{l}\text { Fracasso do } \\
\text { mercado }\end{array}$} & Teoria da Internalização & $\begin{array}{l}\text { Se as empresas enfrentam insucesso do } \\
\text { mercado, prefere-se o IDE, caso contrário } \\
\text { adota-se o licenciamento. }\end{array}$ & $\begin{array}{l}\text { Buckley e Casson } \\
(1976)\end{array}$ \\
\hline & $\begin{array}{l}\text { Teoria Eclética } \\
\text { (Modelo OLI) }\end{array}$ & $\begin{array}{l}\text { Se o mercado local possui (L), prefere-se } \\
\text { a exportação. Se (L) se encontra no } \\
\text { mercado anfitrião com alta vantagem (I) } \\
\text { irá resultar em IDE, caso contrário adota- } \\
\text { se o licenciamento. }\end{array}$ & Dunning (1977) \\
\hline & $\begin{array}{l}\text { Teoria do Custo de } \\
\text { Transação }(\mathrm{CT})\end{array}$ & $\begin{array}{l}\text { Se a transação de um ativo é muito } \\
\text { específica, as empresas preferem modos } \\
\text { que possam dar alto controle no mercado } \\
\text { externo. Caso contrário, pode-se adotar } \\
\text { modos de menor controle. }\end{array}$ & $\begin{array}{l}\text { Anderson e } \\
\text { Gatignon (1986) }\end{array}$ \\
\hline \multirow[t]{2}{*}{$\begin{array}{l}\text { Abordagens } \\
\text { atuais }\end{array}$} & $\begin{array}{l}\text { Teoria Resource-Based } \\
\text { View (RBV) }\end{array}$ & $\begin{array}{l}\text { Em empresas com recursos muito } \\
\text { específicos, prefere-se adotar modos de } \\
\text { alto controle no mercado externo. Caso } \\
\text { contrário, pode-se adotar modos de baixo } \\
\text { controle. }\end{array}$ & $\begin{array}{l}\text { Wernerfelt, } \\
\text { (1984) }\end{array}$ \\
\hline & Teoria da Contingência & $\begin{array}{l}\text { A escolha do modo de entrada depende } \\
\text { de fatores dos ambientes internos e } \\
\text { externos. }\end{array}$ & Okoroafo (1990) \\
\hline
\end{tabular}

Fonte: Adaptado de CUMBERLAND (2006); DECKER; ZHAO (2004); ERRAMILLI; SHARMA (2004).

\subsubsection{Teoria da Vantagem Monopolista}

Dentro do paradigma da imperfeição de mercado, a teoria foi originada pelo autor Hymer (1960/1976), ao estudar Investimentos Diretos Estrangeiros (IDE) de empresas americanas no pós segunda guerra mundial. Subsequentemente, Caves (1971) expandiu essa teoria, acrescentando que a diferenciação do produto é uma vantagem fundamental de propriedade no mercado monopolista (BUCKLEY; CASSON, 2009). 
Essa teoria defende que uma empresa com um produto difícil de ser copiado pode ter maiores retornos e, assim, compensar os altos custos de investimento no mercado estrangeiro. Hymer (1976) acreditava que empresas inseridas em um mercado de produto imperfeito, com vantagens superiores a outras, favoreciam o IDE e seu direcionamento dependia da facilidade de entrada no país-alvo. A economia de escala, as vantagens de conhecimento e a diversificação são as imperfeições de mercado que Hymer (1976) considera como importantes fatores que permitem a obtenção do poder monopolista da empresa em mercados externos (BUCKLEY, 2006).

Para Hymer (1960), existem dois motivos que mostram o IDE como um importante mecanismo para a expansão internacional das empresas: o primeiro é a necessidade de transferência de vantagens organizacionais e tecnológicas da empresa matriz e sua filial no país estrangeiro e o segundo é a eliminação de conflitos, gerada pela necessidade de controlar as operações estrangeiras. Isso força a empresa a fazer investimentos maiores que o necessário para a obtenção de um portfólio ideal. Diferente do conceito tradicional de IDE, que exige um controle das operações no exterior, Hymer adotou a visão de investimento em carteira que permite a participação na propriedade (PITELIS, 2006).

De acordo com Hymer (1960), as empresas entrantes enfrentam custos adicionais, chamados de custos de fazer negócios no exterior (CFNE), relacionados às operações de negócios em ambientes desconhecidos, como despesas para adquirir informações sobre diferenças culturais, políticas e econômicas, como ainda atitudes e ações demandadas por clientes, fornecedores e agências governamentais nos países anfitriões. Para superar tais custos e tornar o negócio lucrativo, as empresas precisam usar seus recursos e vantagens ou adotar ambientes institucionais no país estrangeiro. A ideia de CFNE serviu de base para Zaheer (1995), ao introduzir o conceito de responsabilidade do estrangeiro, que foi visto como um desafio para as empresas em seu processo de internacionalização.

Embora a teoria da vantagem monopolista tenha servido de base para a teoria dos negócios internacionais, esta tem sido criticada por muitos pesquisadores, dada a necessidade de ajustes e atualizações aos conceitos modernos do empreendedorismo global. É uma teoria que explica parcialmente sobre a dimensão de propriedade, incapaz de explicar as condições e motivos pelos quais os modelos de joint ventures ou exportação são escolhidos (ERRAMILLI; 
SHARMA, 2004). Para Pitelis (2006), Hymer não considerou o conceito de criação de valor, em que uma empresa se expande no exterior para adquirir novos recursos e capacidades. Buckley (2006) também destacou que Hymer não focou no tema inovação, visto que isso é um motivo importante para as empresas se expandirem globalmente. Por outro lado, Pearce e Papanastassiou (2006) destacaram que Hymer apontou a inovação em seus estudos, além de acreditar que as multinacionais eram capazes de desenvolver novos produtos de baixo custo em mercados estrangeiros. Outro problema encontrado na teoria de Hymer foi que ele se referenciou na concorrência perfeita, o que é raramente alcançável no mercado. Suas ideias foram baseadas em suas experiências em países do terceiro mundo, no final da era colonial, onde as economias eram pobres e baseadas na agricultura (BUCKLEY, 2006).

As ideias de Hymer sobre as multinacionais foram influenciadas pela abordagem que os governos de países em desenvolvimento tinham sobre as empresas privadas, porém, hoje essa relação parece ser mais amigável, além das multinacionais oferecerem aos países anfitriões recursos que sem elas seriam difíceis de se serem obtidos. Hymer não considerou a ação do governo de países hospedeiros, para a formação de instituições, e sua responsabilidade de estabelecer políticas eficazes para o apoio das multinacionais (DUNNING, 2006).

\subsubsection{Teoria do Ciclo de Vida do Produto Internacional}

Introduzida por Vernon (1966), essa teoria explica que o processo de internacionalização é sequencial e relacionado com o ciclo de vida de um produto. Nos estágios iniciais, uma empresa atende a demanda em um país estrangeiro por meio da exportação, porém, à medida que o produto entra no estágio de maturidade, alguns concorrentes do país estrangeiro, em busca de um maior potencial de lucro, começam a produzir substitutos mais baratos. Vendo isso como ameaça, a empresa exportadora transfere sua unidade de produção para esse mercado, mudando de empresa exportadora para a realização de IDE (ERRAMILLI; SHARMA, 2004). As empresas, ao se depararem com o declínio das demandas, buscam a realocação da produção em países com tecnologias que possuem recursos mais baratos, justificando essa transferência da produção para outros países, no alcance da maturidade do produto (MELIN, 1992). 
Vernon (1966) explica que o processo de internacionalização ocorre durante as quatro etapas do ciclo de vida de um produto, introdução, crescimento, maturidade e declínio. Na introdução, além da produção ser em pequenas escalas, não há padronização e os custos são pouco influenciáveis pois as empresas estão preocupadas em flexibilidade, comunicação e controle. $\mathrm{Na}$ fase de crescimento do produto, as empresas passam a ter maior padronização do produto, ao mesmo tempo cortando os custos de produção para ganharem economias de escala. Ao entrar na fase de maturidade do produto, na busca de maiores lucros, os concorrentes nos países estrangeiros produzem produtos alternativos, motivando as empresas a transferirem sua produção para esses mercados, a fim de manterem sua posição.

Durante a fase de declínio do produto, a demanda em mercados desenvolvidos diminui e as empresas de países hospedeiros entram no mercado americano para competirem com empresas locais, oferecendo produtos alternativos e mais baratos (AGARWAL; MALHOTRA; ULGADO, 2003).

Criticada por generalizar os padrões de globalização, sendo que a escolha do modo de entrada é algo seletivo e estratégico, essa teoria também não considera produtos que, por alguma mudança tecnológica ou regulamentação de mercado, são comercializados sem completarem as quatro etapas do ciclo de vida. Sua principal limitação refere-se a um processo dependente do tempo com um caminho determinístico (ANDERSEN, 1997). Essa teoria é inadequada para empresas de serviços, além de não descrever os produtos com um ciclo de vida curto. O modelo é incapaz de explicar o processo de internacionalização de novos produtos de empresas com experiências anteriores ao processo de expansão internacional (AGARWAL; MALHOTRA; ULGADO, 2003). Essa teoria, como a teoria de Hymer, também possui uma explicação limitada sobre propriedade e ainda não aborda a escolha de diferentes possibilidades de exportação e joint venture (ERRAMILLI; SHARMA, 2004).

\subsubsection{Teoria da Internacionalização}

Essa teoria foi introduzida por Johanson e Wiedersheim-Paul (1975), após estudarem o processo de internacionalização de quatro empresas suecas. Eles argumentaram da necessidade 
das empresas de terem uma atitude internacional que é diretamente afetada ao ganharem experiências na descoberta de barreiras e riscos ao se expandirem internacionalmente. Quanto maior o conhecimento das empresas com o processo de expansão internacional, maior a chance de redução de riscos. A internacionalização, portanto, é um processo gradual com quatro estágios sequenciais de graus distintos de envolvimento internacional e comprometimento de recursos. No primeiro estágio, as empresas operam apenas no mercado interno, sem atividade de exportação. No segundo estágio, as empresas passam a operar no mercado externo, através da exportação por meio de agentes ou intermediários. No terceiro estágio, as empresas já estão seguras para o estabelecimento de uma subsidiária no exterior, e, na quarta e última fase, as empresas passam à produção no país anfitrião. Essa sequência foi denominada de establishment chain e, obviamente, não é esperado de uma empresa que siga toda a cadeia.

A teoria da internacionalização foi originada na teoria comportamental de Cyert e March (1963), e, posteriormente, Johanson e Vahlne (1977, 1990) introduziram o modelo de estágio de internacionalização Uppsala, ou modelo U, em que uma empresa utiliza modos graduais de integração e uso do conhecimento sobre o mercado e operações estrangeiras, para minimizar incertezas e riscos. Outro fator de aumento de incertezas é quando há uma grande distância psíquica, ou seja, são fatores que impedem ou dificultam os fluxos de informação entre a empresa e o mercado, como linguagem, cultura e a prática do desenvolvimento de negócios. Nestes casos, para evitar o risco de investimento, a empresa busca a menor distância psíquica de seu país de origem, focando em mercados com características mais similares ou próximos às suas bases de operações (JOHANSON; WIEDERSHEIM-PAUL, 1975).

Sugerido por Johanson e Vahlne, (1977), o modelo inicial de Uppsala considerava dois mecanismos de mudança por parte das empresas. O primeiro é que as empresas mudam os estágios de internacionalização ao aprenderem com a experiência em mercados estrangeiros, já no segundo, elas mudam em função do comprometimento em suas decisões para fortalecer sua posição no país anfitrião. Esse comprometimento é definido pelo tamanho do investimento multiplicado por seu grau de inflexibilidade.

Modificado em 2009, o modelo de Uppsala teve a substituição do comprometimento do mercado com as redes de negócios. Ao invés de atividades atuais ao modelo, foram acrescentados aprendizado e criação de confiança e de oportunidades como variáveis do 
processo. Os mercados são redes onde as empresas usam seus relacionamentos e estabelecem laços com os membros, podendo entrar em novos mercados enquanto usufruem desses parceiros, que fornecem conhecimentos e recursos (JOHANSON; VAHLNE, 2009).

O modelo de Uppsala tem sido criticado por ter uma abordagem de método de pesquisa experimental, pressupondo que o conhecimento é alcançado através da busca e aprendizado. Os estágios sequenciais propostos são restritos a um país específico e a teoria ignorou os modos de entrada contratuais e por joint ventures (ERRAMILLI; SHARMA, 2004).

\subsubsection{Teoria das Redes}

Após o desenvolvimento do modelo de Uppsala, essa teoria reconheceu que as decisões no contexto da internacionalização são influenciadas, principalmente, pelos relacionamentos que a empresa possui no exterior. Considera que o próprio mercado que a empresa está inserida é visto como uma rede de empresas e tal empresa se apoiará e se desenvolverá dentro desta rede para o processo de internacionalização (HILAL; HEMAIS, 2003).

Esta permite que as empresas criem uma rede de relacionamentos com ações mútuas para alcançarem um objetivo comum, obtendo uma vantagem competitiva não apenas por recursos internos, mas pela interação com outras empresas (COVIELLO; GHAURI; MARTIN, 1998).

As redes são constituídas por três componentes, inter-relacionados, que são os atores, os recursos e as atividades. Os atores, constituídos pela empresa, clientes e fornecedores, constroem e preservam relacionamentos uns com os outros. Essa inter-relação proporciona o acúmulo de conhecimento da empresa e permite a obtenção de informações sobre as condições de mercado no momento certo, afetando as estratégias internacionais (SHARMA; BLOMSTERMO, 2003). Quando uma empresa trabalha em rede com fornecedores e outros atores de negócios no país de origem, esse fato facilita a expandir suas operações no exterior, acumular maior conhecimento experiencial internacional e obter melhores desempenhos (BLOMSTERMO et al., 2004). 
Segundo Coviello, Ghauri e Martin (1998), tanto no país de origem quanto no país anfitrião, o trabalho em rede é feito por relações formais e informais. Essas relações incluem amizades, conexões familiares no exterior, colaboração com outras empresas e ligações com agências governamentais. Malhotra, Agarwal e Ulgado (2003) consideraram as redes de negócios como formais e as redes sociais como relações informais.

Em empresas ou empreendimento novos, é comum a escassez de recursos para o crescimento e sobrevivência no mercado, portanto, uma rede de relações sociais ajuda os empreendedores a ganharem conhecimento e a ingressarem imediatamente em mercados estrangeiros sem experiência suficiente. Os empreendedores entendem que o uso do potencial de mercado para trocar conhecimento e criar relacionamentos mútuos é uma oportunidade que serve como auxílio à exploração desses novos mercados. Esses relacionamentos em rede permitem que as empresas reconheçam essas oportunidades nos mercados internacionais. Entretanto, reconhecer oportunidades é uma ação cognitiva que é feita por indivíduos, ou seja, gerentes ou funcionários e não pela empresa (ELLIS, 2011). Os gerentes devem responder ao ambiente político, às estruturas industriais e às atividades de lobby, tornando as relações com atores sociopolíticos vitais no processo de internacionalização e no desenvolvimento da posição de mercado. A fim de obterem aprovação e apoio desses atores políticos, uma empresa deve adaptar suas atividades aos seus requisitos (ELG; GHAURI; TARNOVSKAYA, 2008).

Alguns autores têm criticado a teoria das redes. As críticas de Malhotra, Agarwal e Ulgado (2003) apontam que essa teoria não explica o processo de internacionalização das empresas que não possuem relações de redes, muito menos mostra algum mecanismo de reconhecimento de contatos de rede que as empresas poderiam usufruir. Complementam que a metodologia qualitativa utilizada nesta abordagem não é capaz de testar a teoria. Para Salmi (2000), as relações entre os atores nas redes de negócios nem sempre são estáveis, e, para uma empresa que entra em uma rede turbulenta, isso irá gerar incertezas e mudanças, principalmente quando o acesso às informações confiáveis for difícil. 


\subsubsection{Teoria da Internalização}

A teoria da internalização tem suas origens no trabalho de Coase (1937), que argumentava que a internalização de transações externas poderia afetar a natureza, a sobrevivência e o crescimento das empresas.

Abordada inicialmente por Buckley e Casson (1976) para expor o crescimento das multinacionais americanas, após a segunda guerra mundial, os autores argumentam que empresas, com o objetivo de minimizar os custos, selecionam as melhores estruturas disponíveis, com base na avaliação dos custos relacionados a cada fase de produção. Se as empresas considerarem qualquer transação como um risco que possa comprometer os recursos, tais transações serão internalizadas.

Com base na teoria da internalização, os mercados são naturalmente imperfeitos. As multinacionais evitam as imperfeições do mercado hospedeiro, ao internalizar suas operações em relação ao conhecimento, matérias-primas, produtos intermediários e bens perecíveis. No entanto, a internalização pode reduzir as economias de escala e resultar em restrições do governo anfitrião ou dificultar na comunicação entre as fronteiras (FISCH, 2008).

Buckley e Casson (1976) sugeriram que a internalização de um mercado externo imperfeito tem cinco vantagens gerais: primeiro, a coordenação de um processo multiestágios que inclui atrasos, mas carece de mercados futuros. Em segundo lugar, o uso eficiente do poder de mercado é facilitado através da desigualdade de preços nos mercados internos. Em terceiro lugar, a instabilidade é reduzida devido à concentração bilateral de poder de mercado. Em quarto lugar, a disparidade de conhecimento entre compradores e vendedores é eliminada. Em quinto lugar, a responsabilidade tributária sobre transações internacionais é reduzida pelo preço de transferência interna. As empresas devem comparar esses cinco pontos com os custos de internalização, incluindo os altos custos de alocação de recursos em mercados internos, aumento dos custos de comunicação, problemas políticos no mercado externo e os custos de gerenciamento de operações múltiplas. 
A teoria da internalização considera como padrão os modos de entrada de baixo controle em mercados estrangeiros. As empresas somente irão adotar o IDE e estabelecerão suas instalações no exterior quando os custos relacionados a transações de exportação e licenciamento forem maiores que os custos de transações internas (EKELEDO; SIVAKUMAR, 2004).

De acordo com Buckley e Casson (1998), durante a entrada no mercado externo, uma empresa enfrentará custos extras, incluindo custos de adaptação, custos de marketing e os custos de construção de confiança nos mercados estrangeiros. Na exportação, as empresas suportam custos adicionais, como tarifas e custos de transporte.

Para explicar os motivos que as empresas, quando comparam os custos, decidem exportar seus produtos ou serviços para alguns mercados e investirem em outros, Buckley e Casson (1998) modificaram a teoria da internalização argumentando que as empresas são capazes de explicar, em detalhes, as funções de produção e distribuição, reconhecer a concorrência no país anfitrião, diferenciar a vantagem de propriedade da vantagem de internalização e reconhecer a importância da confiança estabelecida nos acordos de joint venture.

Com base nos modelos econômicos de Hirsch (1976), as empresas devem decidir onde localizar suas operações, marketing e atividades de P\&D. As empresas também devem decidir quais atividades devem internalizar ou externalizar para minimizar os custos. Essas decisões são afetadas por dois fatores, sendo eles, os custos de transferência de conhecimento e a relação entre custos fixos e custos variáveis (BUCKLEY; HASHAI, 2005).

Algumas críticas apontadas por autores relacionam que, em primeiro lugar, esta teoria não mostra o efeito das vantagens de localização na escolha do modo de entrada. Em segundo lugar, a teoria pressupõe que a competição no país anfitrião envolve uma empresa monopolista com tecnologia inferior que é inativa ao lidar com a empresa entrante, enquanto nos mercados atuais a natureza da concorrência é diferente e dinâmica. Em terceiro lugar, seu foco na minimização de custos é limitado, pois não inclui empresas motivadas à expansão internacional para aprimorar suas capacidades (ERRAMILLI; SHARMA, 2004). Essa teoria também não explica a incerteza causada pelo comportamento de parceiros locais em uma joint venture ou grandes problemas relacionados a fusões e aquisições (FISCH, 2008). 


\subsubsection{Teoria Eclética}

Dunning (1977) introduziu a teoria eclética sobre a localização das atividades econômicas. O termo "eclético" refere-se ao fato de que o modelo de Dunning incorpora várias abordagens teóricas, como as vantagens de propriedade introduzidas pela teoria do crescimento da firma proposta por Penrose (1959), a teoria da vantagem monopolista de Hymer (1960), vantagens de localização explicadas por Vernon (1966), e as visões de custo de transação de Buckley e Casson (1976), ou a teoria de internalização (DECKER; ZHAO, 2004).

Como mostra a Figura 3, a teoria eclética sugere que as empresas decidirão suas atividades de IDE e exercerão controle sobre seus recursos se tiverem três vantagens principais: vantagens de propriedade $(\mathrm{O})$; vantagens de localização (L); e vantagens de internalização (I). Assim, essa teoria também é conhecida como modelo OLI (AGARWAL; RAMASWAMI, 1992).

No modelo OLI, as vantagens de propriedade $(\mathrm{O})$ mostram como os recursos exclusivos e sustentáveis específicos de uma empresa, sendo competitivas ou monopolísticas, ajudam a competir com concorrentes locais em mercados estrangeiros. Estas incluem recursos específicos da empresa, o tamanho e o potencial do mercado no país de origem. Se uma empresa pode utilizar suas vantagens de propriedade $(\mathrm{O})$ efetivamente no momento da entrada, ela pode alcançar uma posição de mercado superior, embora esses ativos não sejam todos transferíveis internacionalmente. As vantagens da localização (L) dependem da disponibilidade e do custo dos recursos que devem ser comprometidos por uma empresa em um mercado externo, bem como as barreiras à entrada e os riscos expostos. Se o potencial de mercado em um país é alto e os riscos de investimento são baixos, uma empresa terá um negócio lucrativo. Por outro lado, se os riscos são altos, as empresas preferem explorar suas vantagens de propriedade $(O)$, através do IDE, ao invés de vendê-las ou licenciá-las para outras empresas no mercado-alvo (BUCKLEY; HASHAI, 2005).

As vantagens de propriedade $(\mathrm{O})$ explicam quem pode localizar suas operações no exterior, as vantagens de localização (L) mostram onde localizar as operações, e as vantagens de internalização (I) indicam por que uma empresa escolhe o IDE em vez de licenciar sua tecnologia e marca (AGARWAL; RAMASWAMI, 1992). 
Figura 3 - Vantagens da teoria Eclética

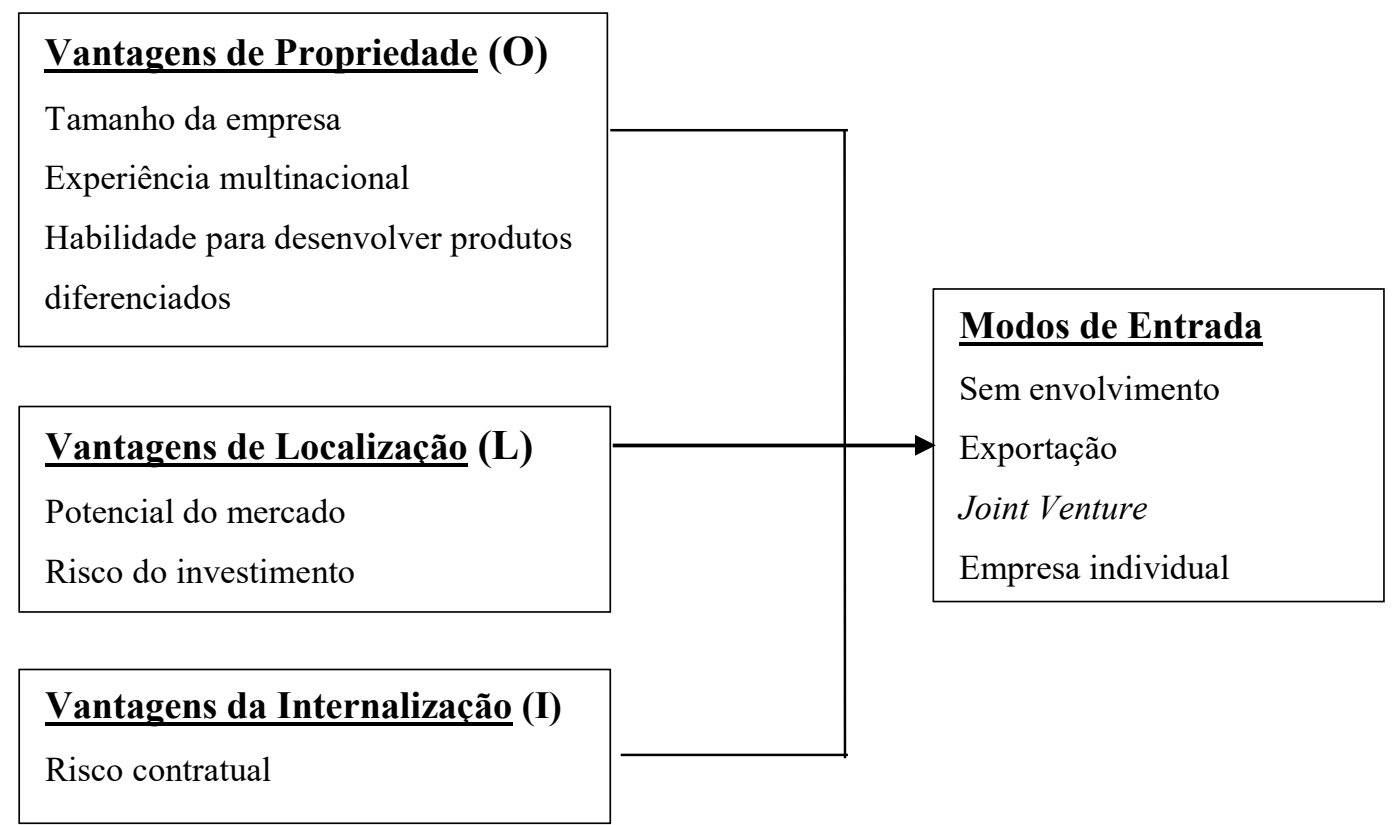

Fonte: Elaborado pelo autor, adaptado de Agarwal e Ramaswami (1992).

Em outras palavras, se o país de origem de uma empresa tiver uma vantagem de localização em relação ao país anfitrião, a empresa escolherá exportar como seu modo favorito. Por outro lado, se a vantagem de localização for no país anfitrião, a empresa considera potencial risco de fazer cumprir contratos com parceiros. Porém, se o risco contratual for superior ao custo de internalização, o IDE será o melhor modo de operação e, quando o risco contratual for baixo, a preferência será por licenciamento (DUNNING, 1980). Segundo Carneiro e Dib (2007), além da vantagem de localização, existem dois tipos de vantagens de propriedade. Uma derivada da propriedade particular da empresa, por exemplo, uma tecnologia específica, e a outra vantagem derivada da propriedade de ativos complementares, como a capacidade de criar novas tecnologias. A vantagem de internalização é oriunda da facilidade com que a empresa consegue, integralmente, apropriar o retorno integral de sua propriedade de ativos como benefícios transacionais.

Com as mudanças tecnológicas e políticas dos anos noventa, Dunning (2015) tentou reconfigurar a teoria eclética e passou a considerar as capacidades dos parceiros, as estruturas conjuntas e integração de espaços. Nesta nova abordagem, foi apresentado um conceito mais amplo das vantagens de propriedade e as vantagens de localização, foram incluídos fatores de sucesso nas alianças estratégicas, além da capacidade do acúmulo de conhecimento, inovação, padrões tecnológicos e o papel dos blocos comerciais. As vantagens de internalização 
superaram os custos de transação e passaram a considerar objetivos mais dinâmicos, como busca de eficiência (AGARWAL; MALHOTRA; ULGADO, 2003).

O modelo OLI baseia-se nas experiências de grandes multinacionais dos EUA e de outros países desenvolvidos, enquanto as empresas dos países em desenvolvimento diferem em suas vantagens e estratégias internacionais. As multinacionais dos países desenvolvidos são pioneiras e podem acessar os recursos necessários para a expansão internacional. No entanto, as born globals, ou empresas que já nascem multinacionais, incluindo os novos empreendimentos internacionais e as multinacionais emergentes, são retardatárias e possuem menos recursos. Por sofrerem de desvantagens de localização, como infraestrutura fraca e instituições pouco desenvolvidas em seus países de origem, elas vão para o exterior para obter recursos e construir vantagens. Em outras palavras, em teorias tradicionais como o modelo OLI, as multinacionais se internacionalizam quando têm vantagens, enquanto as multinacionais emergentes usam o IDE para se expandirem internacionalmente, construírem vantagens e obterem recursos (DUNNING, 2000). Uma crítica à teoria eclética é o foco nas vantagens de localização, pois isso especialmente pode confundir a relação entre a seleção de mercado e a escolha do modo de entrada (AGARWAL; MALHOTRA; ULGADO, 2003). Essa teoria também ignora o efeito dos fatores do país de origem, a natureza dos produtos, os recursos específicos da empresa, os custos de transporte e as taxas de câmbio na escolha do modo de entrada (EKELEDO; SIVAKUMAR, 2004).

\subsubsection{Teoria do Custo de Transação}

A teoria do custo de transação (CT) foi introduzida por Anderson e Gatignon (1986), com o objetivo de explicar o motivo que leva as empresas decidirem estabelecer uma linha de produção em um mercado estrangeiro, ao invés de expandirem através de licenciamento ou contratos com empresas dos países anfitriões. O modelo de custo de transação é uma extensão adicional da teoria da internalização, e, devido às suas ideias comuns sobre o papel dos custos de transação na internalização de atividades de negócios, essas duas visões são algumas vezes consideradas como uma única teoria (EKELEDO; SIVAKUMAR, 2004). 
Williamson (1975) também é considerado como um fundador, pois ele contribuiu com a abordagem da teoria do custo de transação econômica (CTE) e a integração vertical das empresas. Essa abordagem considera a minimização de custos para determinar um modo de entrada de governança nos mercados estrangeiros. Williamson identificou três condições principais de transações que afetam a escolha do modo de governança: especificidade do ativo, o tamanho e a frequência da transação e as incertezas, comportamentais internas e do ambiente externo. Em outras palavras, quando o mercado é grande e as transações são frequentes, e também quando os ativos de uma empresa têm outro uso limitado, as empresas favorecem a internalização para minimizar, entre outros problemas, os oportunismos e os custos de transação (RUTASHOBYA; JAENSSON, 2004). Anderson e Gatignon (1986) argumentam que a empresa entrante possui opção de escolha quando o mercado do país anfitrião é grande o suficiente para recuperar o alto custo de um modo de operação de alto controle. Assim, a teoria da transação sugere que, para um modo de entrada eficiente, os custos de transação e os custos de controle são influenciados por quatro fatores, incluindo a transação de ativos específicos, ou seja, investimentos físicos ou humanos especializados; a incerteza interna comportamental; a incerteza externa ambiental; e a frequência das transações. As empresas que possuem ativos específicos são dependentes de recursos físicos e humanos, enfrentando custos de transação mais altos. Quando a incerteza interna ou comportamental é alta, os custos de transação aumentarão devido ao comportamento oportunista dos parceiros. A incerteza externa ou ambiental está relacionada ao risco país percebido, devido à instabilidade macroeconômica, restrições do governo, distância sociocultural e mudanças políticas.

Para Malhotra, Agarwal e Ulgado (2003), a especificidade de ativos causa custos de proteção, os resultados de incerteza comportamental nos custos de desempenho e a incerteza ambiental causam custos de adaptação. Se esses custos excederem as vantagens de custo de produção em um mercado-alvo, os modos de alto controle são preferidos. Caso contrário, a contratação é uma escolha apropriada. As empresas com alta especificidade de ativos favorecem as subsidiárias integrais para obter retornos mais altos e obter mais eficiência. Se os custos das atividades de negócios de integração forem altos, as empresas com menor especificidade de ativos preferem a joint venture. Quando a incerteza comportamental é alta, as empresas preferem o IDE ao licenciamento. 
Para essa teoria, a unidade de análise são os custos de transação, em que esses estão relacionados à negociação e implementação dos contratos e monitoramento do desempenho dos parceiros de negócios (EKELEDO; SIVAKUMAR, 2004). As empresas podem suportar outros custos de transação para detectar e parar o comportamento oportunista de seus parceiros de negócios, mas esses custos não são totalmente considerados pela teoria de transação. As empresas comparam os custos de transação com os custos de integração de atividades internas, resultando na internalização de operações estrangeiras e permitindo a escolha de uma estrutura de governança mais adequada (AGARWAL; MALHOTRA; ULGADO, 2003).

A teoria do custo de transação é criticada por não citar o papel das vantagens de localização e seus custos relacionados ao potencial de mercado (EKELEDO; SIVAKUMAR, 2004).

\subsubsection{Teoria Baseada em Recursos}

Originada da teoria da vantagem monopolista de Hymer (1960), a teoria da visão baseada em recursos argumenta que uma empresa com recursos abundantes, com o poder de usá-los com sucesso, poderá competir nos mercados internacionais e atingir suas metas de longo prazo (ERRAMILLI; SHARMA, 2004). Esses recursos são definidos como "qualquer coisa que possa ser pensada como uma força ou fraqueza de uma determinada empresa" (WERNERFELT, 1984, p. 172). Esses recursos não estão igualmente distribuídos entre as empresas dentro de um setor. Cada empresa tem seus ativos exclusivos e que são chamados de recursos específícos da empresa (CARPANO; RAHMAN; ROTH, 2003). Mesmo com o argumento de Porter (1980), sobre as forças competitivas, relacionadas à estrutura da indústria, serem os principais fatores que levam a empresa ao sucesso, a visão baseada em recursos insiste na importância dos recursos específicos da empresa (GALBREATH; GALVIN, 2008). Esses recursos específicos

podem ser tangíveis, como ativos físicos, recursos financeiros e força de trabalho, ou intangíveis, como a propriedade tecnológica, conhecimento, experiência empresarial, marca e cultura organizacional (CARPANO; RAHMAN; ROTH, 2003).

Para Almor e Hashai (2004), uma empresa possui uma variedade de ativos tangíveis e intangíveis, inter-relacionados, que geram habilidades organizacionais, como a capacidade da 
empresa de realizar uma tarefa específica e aumentar a eficiência de suas operações, além de poder aumentar o valor do cliente. Essas capacidades ajudam a empresa a transformar seus recursos em produtos ou serviços que são intangíveis e diferem-se das habilidades intangíveis, dado que estas requerem conhecimento e são relacionadas aos indivíduos e empresas. Os recursos intangíveis compreendem os conhecimentos explícitos, independentes dos indivíduos, além de estarem sob proteção legal, enquanto as capacidades são de difícil proteção.

Na teoria da visão baseada em recursos, a unidade de análise é a empresa e o foco está em seus recursos. O critério para a tomada de decisão é o trade-off entre valor e custo, o que significa que uma empresa que possui recursos valiosos pode suportar os custos de internalização e evitar altos custos de transação (ERRAMILLI; SHARMA, 2004). Desta forma, a capacidade e os ativos valiosos de uma empresa geram eficiência de custo para a própria organização. Empresas com recursos valiosos tendem para a diversificação, entrando nos mercados-alvo onde as demandas correspondem à sua capacidade de recursos (CUMBERLAND, 2006). A capacidade de uma empresa de criar vantagem competitiva em um país anfitrião depende da extensão em que a empresa pode transferir seus valiosos recursos para esse mercado e utilizá-los com eficiência e eficácia. Essa transferência é uma condição essencial para que as empresas tenham sucesso em operações estrangeiras (ERRAMILLI; SHARMA, 2004).

Para Agarwal, Malhotra e Ulgado (2003), uma empresa com recursos e capacidades valiosos não precisa colaborar com empresas locais, ao invés disso, ela própria favorece tais mercados estrangeiros com a existência da abertura da subsidiária. Mesmo sendo o modo padrão de entrada em mercados estrangeiros, um segundo método adotado como modo de entrada são as joint ventures, pois as empresas obtêm conhecimento, recursos e ativos complementares (EKELEDO; SIVAKUMAR, 2004).

Na teoria baseada em recursos, a base para a escolha do modo de entrada é o grau de controle que as empresas têm ou podem ter. Ekeledo e Sivakumar (2004) ofereceram um modelo modificado, dividindo os modos de entrada em modos de alto controle e modos de baixo controle. Um modo de alto controle, ou propriedade exclusiva, exige maior comprometimento de recursos. Com base nesse modelo, a escolha do modo de entrada é determinada pelos recursos específicos da empresa, que se referem a alternativas ou limitações de marketing com as quais a empresa precisa lidar devido à força ou fraqueza de seus recursos e capacidades. 
Além disso, as variáveis de localização são determinantes secundárias. Este modelo assume que as empresas são diferentes com base na natureza do produto que oferecem. Em outras palavras, as empresas de manufatura e de serviços industriais tomam decisões de entrada diferentes das firmas de serviços mais simples, devido à questão da facilidade em separar sua produção e devido também à forma de consumo de cada uma. Como nos serviços industriais, a produção e o consumo são simultâneos, requerem uma distância física menor da empresa. Como essas empresas precisam oferecer um alto padrão de qualidade dos seus serviços, é necessário um alto controle sobre as suas operações. Com isso, essas empresas preferem o modo de entrada de subsidiária própria, e, se elas decidirem colaborar com parceiros locais, irão franquear sua operação para controlar a qualidade dos serviços prestados sob sua marca.

A teoria da visão baseada em recursos tem sido criticada por pesquisadores por ser estática e não explicar como um recurso específico pode criar vantagem competitiva durante a fase da falta de conhecimento suficiente sobre a produtividade de cada ativo individual (CUMBERLAND, 2006). Para Carpano, Rahman e Roth (2003), a teoria baseada em recursos concentra-se na heterogeneidade dos recursos de uma empresa dentro de uma indústria e não considera o papel do contexto institucional em que uma empresa administra seus negócios.

\subsubsection{Teoria da Contingência}

Essa teoria originou-se no modelo de contingência de Fiedler (1967), que sugeriu que o estilo de liderança depende de vários fatores situacionais, incluindo relações entre membros-líder, estrutura de tarefas e poder de posição do líder. Na teoria da contingência, os gerentes buscam uma escolha satisfatória e não ótima. Eles tomam decisões sob restrições organizacionais e ambientais (CUMBERLAND, 2006). A literatura de internacionalização tem oferecido diferentes modelos para a escolha do modo de entrada, porém sempre orientados para o conteúdo e ignorando o papel dos tomadores de decisão (DECKER; ZHAO, 2004). Sendo assim, no início dos anos 90, os pesquisadores ofereceram a teoria de contingência ou da abordagem da estratégia de negócios (OKOROAFO, 1991). A abordagem da estratégia de negócios é uma visão pragmática em que as empresas adotam suas estratégias de expansão por meio de trade-offs entre vários fatores, como atratividade do mercado, recursos específicos da 
empresa e atitudes gerenciais (WHITELOCK, 2002). Para Ekeledo e Sivakumar (2004), há três visões estratégicas sobre a tomada de decisões: primeiro, a visão específica da situação, na qual as decisões da empresa estão relacionadas às situações únicas com as quais ela lida; segundo, a visão universal, na qual as leis universais estratégicas são aplicáveis a todas as empresas e em todas as situações; e terceiro, a visão de contingência, na qual não há uma escolha ótima universal para todas as empresas e situações, mas a escolha ótima depende de um conjunto de condições organizacionais e ambientais.

Segundo Rundh (2001), as empresas não seguem necessariamente os modelos de estágio de internacionalização, mas podem precisar expandir suas atividades para mercados estrangeiros em um estágio inicial de suas operações devido ao mercado interno limitado. Consequentemente, os tomadores de decisão escolhem o modo de entrada apropriado com base na posição de mercado da empresa. Na teoria da contingência, a unidade de análise é o tomador de decisão, que se refere aos gerentes do topo de uma firma que tomam a decisão de expansão e a escolha do modo de entrada. Eles tentam simplificar a tarefa da decisão, consideram apenas algumas variáveis, usam um processo hierárquico e decompõem o problema em subsistemas estáveis e o ambiente em subsistemas constantes (CUMBERLAND, 2006).

Na teoria da contingência, a tomada de decisão estratégica depende das características dos tomadores de decisão. Os decisores devem ter o conhecimento das estratégias disponíveis, capacidade de executar a estratégia com sucesso e motivação para tomar uma decisão rápida e selecionar uma estratégia apropriada. Uma decisão pode ser simples e bem-definida ou complicada e mal-definida e o ambiente de decisão também pode afetar a escolha (BEACH; MITCHELL, 1978).

Como variáveis que não estão sob o controle de uma empresa, esses ambientes podem ser o ambiente político e a distância cultural. Os pesquisadores também acrescentaram fatores organizacionais, como diferenciação de produto, para fornecer uma estrutura mais ampla de fatores que afetam a estratégia da empresa (EKELEDO; SIVAKUMAR, 1998).

Para Woodcock, Beamish e Makino (1994), o nível de comprometimento de recursos depende dos riscos percebidos pelas empresas em relação aos seus recursos críticos e capacidades nos mercados estrangeiros, além da cultura organizacional ser considerada uma ameaça para fusões 
e aquisições. Decker e Zhao (2004) argumentam que, ao decidirem entrar em mercados estrangeiros, os gerentes são propositadamente racionais e visam adotar um modo que maximize o lucro da empresa. No entanto, eles enfrentam limitações de tempo, informação e recursos. Como é difícil avaliar todas as alternativas disponíveis, as empresas precisam usar uma estratégia de tomada de decisão hierárquica que limite suas escolhas às alternativas mais satisfatórias em relação a cada decisão.

Kumar e Subramaniam (1997) ofereceram um modelo de contingência no qual cinco etapas são usadas para selecionar um modo de entrada adequado. Nesse modelo, os gerentes seguem um processo lógico, no qual, avaliando tempo, recursos e qualidade da informação, passam por todo o processo, desde reconhecerem a necessidade de expansão até a escolha do modo de entrada. Gao (2004) ofereceu um modelo de contingência modificado, usando poder de barganha e confiança, para justificar a escolha entre diferentes modos de entrada em termos de participação acionária. Nesse modelo, a escolha do modo de entrada está relacionada ao grau de controle e ao nível de comprometimento de recursos. O controle mostra até que ponto uma empresa pode garantir o comportamento de seus parceiros. Assim, menor confiança resulta no maior nível de controle. A escolha estratégica do modo de entrada é uma decisão estrutural, devendo, assim, ser ajustada aos objetivos estratégicos da empresa, bem como aos recursos e capacidades internos e às forças externas do ambiente, porque o nível de desempenho depende do grau de ajuste entre esses fatores.

A teoria da contingência também recebeu críticas. Para Cumberland (2006), não há uma definição clara para as variáveis de contingência e suas medições operacionais. Para Whitelock (2002), a abordagem da contingência ignora as relações de rede que uma empresa precisa para sua expansão internacional.

\subsection{Modos de entrada no mercado estrangeiro}

Segundo Deresky (1997), após a escolha e definição do mercado de expansão, a decisão seguinte - e a mais crítica - é a decisão da melhor forma de entrada neste novo mercado. Os dirigentes precisam entender o modo como sua empresa irá melhor atender às necessidades dos 
novos mercados potenciais, considerando-se os riscos e outros fatores críticos associados às suas estratégias de entrada.

Para Khanna, Palepu e Sinha, (2005), na fase do processo de escolha do território de expansão, é recomendado, de início, realizar uma análise do contexto institucional de cada país, incluindose os seus sistemas políticos e sociais, bem como a receptividade para investimentos estrangeiros e a qualidade de produtos, mão de obra e mercados de capitais existentes nestes países. Uma vez estudados tais fatores, a decisão a ser tomada seria contornar as fraquezas institucionais encontradas, criando uma nova infraestrutura de mercado para o seu negócio, ou então não entrar no país, por entender que adaptar o seu modelo de negócio é impraticável ou economicamente inviável.

Dias, Rocha e Silva (2014), ao fazerem uma revisão de estudos na literatura internacional, mencionam que a escolha dos modos de entrada origina-se de duas condições distintas: a primeira quando a empresa não tem capital próprio, em que, na literatura pesquisada por eles, foram observados os modos escolhidos como exportações diretas ou indiretas, também através de arranjos, licenciamentos, franquias, alianças e contratos; e a segunda condição, quando a empresa dispõe de capital próprio, mostrando que os modos de entrada são escolhidos na hierarquia de decisão baseada na análise e definição de fatores como o tipo de atividade que ela quer exercer no mercado internacional, se produção ou distribuição, o nível de propriedade que terá a empresa, ou seja, se será uma subsidiária de controle integral ou uma join venture, e, por último, como será a formação do estabelecimento, por aquisição ou modelo greenfield, termo em inglês usado para referenciar a criação de nova empresa.

Para efeito de explanação da teoria dos modos de entrada, baseou-se o Quadro 2, abaixo, com cada modo e suas principais características. 
Quadro 2 - Modos de entrada e características

\begin{tabular}{|c|l|}
\hline Modos de entrada & \multicolumn{1}{c|}{ Principais características } \\
\hline Exportação & Custo de transporte elevado, pouco controle sobre o mercado anfitrião \\
\hline Licenciamento & Baixo custo, pouco risco, pouco controle sobre o mercado e baixos retornos \\
\hline Alianças estratégicas & $\begin{array}{l}\text { Custos, recursos e riscos compartilhados, problemas de integração (por } \\
\text { exemplo, duas culturas corporativas) }\end{array}$ \\
\hline Aquisição & $\begin{array}{l}\text { Rápido acesso ao novo mercado, custo elevado, negociações complexas, } \\
\text { problemas para fundir-se com operações domésticas }\end{array}$ \\
\hline $\begin{array}{c}\text { Nova subsidiária } \\
\text { totalmente própria }\end{array}$ & $\begin{array}{l}\text { Operação complexa, muitas vezes custosa, risco elevado, máximo controle sobre } \\
\text { a operação, retornos potenciais acima da média }\end{array}$ \\
\hline
\end{tabular}

Fonte: Elaborado pelo autor, adaptado de Hitt, Ireland e Hoskisson (2011, p. 223).

\subsubsection{Exportação}

A exportação é um modelo muito usado para as empresas que iniciam sua expansão internacional. Apesar de não implicar gastos com o estabelecimento de operações no país anfitrião, o exportador deve estabelecer alguns veículos de marketing e de distribuição, além de desenvolver acordos contratuais com empresas no mercado externo. Os custos de transporte são altos e normalmente há a aplicação de tarifas. O exportador tem baixo controle sobre o marketing e a distribuição de seus produtos (HITT; IRELAND; HOSKISSON, 2011).

A exportação pode ser classificada como direta e indireta. Nas exportações indiretas, a empresa exportadora não tem contato direto com o consumidor ou cliente no exterior, podendo haver um ou mais intermediários no processo. As principais vantagens da existência de intermediários é uso do conhecimento do mercado que esses intermediários possuem, o baixo nível de riscos e o menor comprometimento de recursos. O baixo controle sobre o mercado no país anfitrião é a sua principal desvantagem. Nas exportações diretas, existe um maior envolvimento e risco para a empresa exportadora. Por haver um maior gerenciamento das operações e fluxos das informações entre a empresa e mercado, obtém-se melhores resultados (JEANNET; HENNESSEY, 2004; KOTABE; HELSEN, 2000). 


\subsubsection{Licenciamento}

Segundo Jeannet e Hennessey (2004), a modalidade de licenciamento é quando uma empresa licenciadora coloca um determinado bem ou ativos à disposição de uma empresa licenciada, recebendo royalties ou alguma outra forma de remuneração. Os riscos e investimentos nas instalações de manufatura, marketing e distribuição das mercadorias, ou serviços, são assumidos pela empresa licenciada. Assim, uma principal vantagem do licenciamento é que possivelmente seja o modo de menor custo no processo de expansão internacional (HITT; IRELAND; HOSKISSON, 2011).

Outras vantagens do licenciamento consistem no baixo custo para a empresa licenciadora em produzir uma mercadoria no exterior, ao fácil acesso a parceiros locais, e, consequentemente, acesso a informações de mercado e canais de distribuição, minimizando incertezas oriundas dos riscos políticos e econômicos (JEANNET; HENNESSEY, 2004).

As desvantagens do licenciamento é que ele oferece pouco controle sobre a fabricação e o marketing, além de oferecer um retorno baixo para a empresa licenciadora, pois os ganhos com a operação devem ser divididos entre a empresa e o licenciado. Outra desvantagem é o risco de absorção de tecnologia, criando, para a empresa licenciada, a capacidade de produzir e vender um produto competitivo e semelhante após o término da licença (HITT; IRELAND; HOSKISSON, 2011).

\subsubsection{Alianças estratégicas}

Alianças estratégicas são contratos de parcerias firmados entre organizações de diferentes países, com diferentes finalidades, defesa ou conquista de mercado, reestruturações ou divisão de custos de investimentos (KOTABE; HELSEN, 2000). 
Um exemplo de aliança estratégica são as joint ventures, permitindo às empresas parceiras internalizar as operações sem precisarem arcar com os custos de uma fusão ou investimento direto (BUCKLEY; CASSON, 1996).

As vantagens das joint ventures estão no alto potencial de retorno, o compartilhamento de tecnologias, conhecimento imediato do mercado local, rápido acesso aos canais de distribuição, além da divisão dos riscos e investimentos (KOTABE; HELSEN, 2000).

Existem muitos casos de fracassos nas alianças estratégicas e os principais motivos incluem incompatibilidade e conflitos entre os sócios. A confiança mútua entre os sócios é crucial e sofre interferência por questões como a condição inicial do relacionamento, o processo de negociação, as interações entre os sócios, fatores externos e as culturas territoriais envolvidas na aliança ou joint venture (HITT; IRELAND; HOSKISSON, 2011).

\subsubsection{Aquisição}

Segundo Hitt, Ireland e Hoskisson (2011), “Uma aquisição é uma estratégia pela qual uma empresa compra o controle, ou 100\%, de outra empresa com a intenção de tornar a empresa adquirida uma subsidiária em seu portfólio".

A modalidade de internacionalização por aquisições requer um nível maior de comprometimento da empresa investidora, pelos riscos e controles demandados envolvidos, porém, tende a propiciar retornos superiores comparados às demais modalidades estudadas (OSLAND; TAYLOR; ZOU, 2001).

Apesar de se transformarem em um meio popular de entrada nos mercados internacionais, as aquisições geralmente requerem o financiamento de dívidas, o que implica em custos adicionais, além das negociações internacionais serem mais complexas do que as negociações para aquisições locais. Isso ocorre devido às diferentes culturas sociais e corporativas, potencialmente diferentes (HITT; IRELAND; HOSKISSON, 2011). 


\subsubsection{Subsidiária própria}

Também conhecida como greenfield venture, essa modalidade apresenta alta complexidade e altos custos, porém, proporciona máximo controle à empresa e oferece potencial de ganhos acima da média se comparada com as outras modalidades. Pela necessidade de absorver o conhecimento e expertise sobre o mercado anfitrião, normalmente a empresa contrata funcionários da concorrência ou consultores locais, mantendo, assim, o controle sobre a tecnologia, marketing e distribuição dos seus produtos (HITT; IRELAND; HOSKISSON, 2011).

Para Hill (2013), esta forma de internacionalização é normalmente mais lenta, com riscos altos de insucesso quando os fundadores da subsidiária não conhecem bem o mercado e o ambiente econômico, político e cultural do país em que estão ingressando.

\subsection{Barreiras à entrada}

Com o objetivo de crescimento, empresas ingressam em novos mercados introduzindo produtos novos, ou modificados, ou ainda com produtos idênticos aos existentes no mercado. Em qualquer dos casos, as empresas entrantes enfrentam barreiras à entrada e riscos financeiros (KARAKAYA; STAHL, 1989). Porter (1980) enfatiza que as barreiras à entrada são vantagens inerentes às empresas existentes versus as empresas entrantes.

Para Hitt, Ireland e Hoskisson (2011), identificar novas empresas entrantes é importante pois elas podem ameaçar a participação de mercado das empresas existentes, e são dois os fatores que propiciam a entrada destas novas empresas: barreiras à entrada e a retaliação potencial esperada das empresas já estabelecidas no país.

O autor pioneiro nos estudos sobre barreiras à entrada foi Bain (1956), que as definiu, principalmente, como economias de escala, diferenciação de produto e vantagens de custo absoluto. 
Porter (1980) descreve que as barreiras mais importantes e de destaque da literatura são formadas por 6 fontes principais: 1) economia de escala (quanto maior a empresa, menor o custo de fabricação); 2) diferenciação de produtos (os clientes acreditam que um produto é exclusivo pela boa campanha publicitária ou pela empresa ter sido a primeira a comercializar o produto ou serviço); 3 ) requisitos de capital (competir em um novo mercado requer capital para investir em instalações físicas e marketing); 4) custos de mudança (custos dos clientes por mudarem de fornecedor); 5) acesso a canais de distribuição (uma vez criada a relação com distribuidores, as empresas criam barreiras para novos entrantes, que precisam normalmente custear a entrada nesses canais de relações já estabelecidas, como concorrente); e 6) políticas governamentais (o governo controla a entrada de novos entrantes por meio de licenças de funcionamento).

Para Kotler (1986), barreiras internacionais incluem também requisitos legais discriminatórios, favoritismos políticos, cartéis, fatores culturais e sociais, canais de distribuição e dificuldade bilateral de cooperação de executivos e governos estrangeiros.

Em estudos mais recentes, Karakaya (1993) complementa que, diferentemente das barreiras à entrada em mercados domésticos, as barreiras em mercados internacionais são:

1) Barreiras culturais;

2) Idioma;

3) Acesso a canais de distribuição;

4) Custo de mudanças;

5) Políticas governamentais (taxas, imposição por licenciamentos, controles, cotas de importação e restrições de exportação);

6) Adaptação de produtos;

7) Estabilidade da taxa de câmbio;

8) Esperada concorrência local e global;

9) Mudanças necessárias para atividades promocionais;

10) Nacionalismo;

11) Ambiente político;

12) Ambiente econômico;

13) Corrupção; 
14) Vantagens de custos das empresas locais.

Finalmente, para demonstrar de forma generalizada o desafio em se fazer novos negócios no Brasil, o relatório Doing Business, do World Bank Group (2017), mostra que o Brasil ocupa, em 2018, a posição 125 , do total de 190 países, na classificação relativa à facilidade em se fazer negócios. A Tabela 1 mostra os 11 conjuntos de indicadores analisados onde a distância até a fronteira (DAF) corresponde à posição de cada conjunto numa nota entre 0 e 100, sendo 100 a nota máxima, ou seja, a chegada até a fronteira.

Tabela 1 - Classificação Doing Business 2018 - Brasil

\begin{tabular}{|c|c|c|c|c|}
\hline TÓPICOS & $\begin{array}{l}\text { Classificação } \\
\text { DB } 2018\end{array}$ & $\begin{array}{l}\text { DB } 2018 \\
\text { DAF }\end{array}$ & $\begin{array}{l}\text { DB } 2017 \\
\text { DAF }\end{array}$ & $\begin{array}{l}\text { Mudança na pontuação DAF } \\
\text { (pontos percentuais) }\end{array}$ \\
\hline GLOBAL & 125 & 56.45 & 56.07 & 合 0.38 \\
\hline Pagamento dos I mpostos & 184 & 32.97 & 32.97 &.. \\
\hline Abertura de Empresas & 176 & 65.05 & 65.04 & $\uparrow 0.01$ \\
\hline Obtenção de Alvarás de Construção & 170 & 49.83 & 49.79 & $\uparrow 0.04$ \\
\hline Comércio Internacional & 139 & 59.78 & 55.57 & ^ 4.21 \\
\hline Registro de Propriedades & 131 & 52.60 & 52.62 & 0.02 \\
\hline Obtenção de Crédito & 105 & 45.00 & 45.00 & .. \\
\hline Resolução de I nsolvência & 80 & 47.46 & 49.15 & $\downarrow 1.69$ \\
\hline Execução de Contratos & 47 & 66.00 & 66.00 & .. \\
\hline Obtendo Eletricidade & 45 & 82.46 & 81.23 & $\uparrow 1.23$ \\
\hline Proteção dos investidores minoritários & 43 & 63.33 & 63.33 &.. \\
\hline
\end{tabular}

Fonte: Elaborado pelo autor, adaptado de World Bank Group (2017).

Pode-se observar que os 6 piores índices para o Brasil são: pagamento dos impostos, abertura de empresas, obtenção de alvarás de construção, comércio internacional, registro de propriedades e obtenção de crédito. Felizmente, em comparação com o ano anterior, o índice de maior ascensão, rumo à fronteira, foi o comércio internacional. 


\section{METODOLOGIA DA PESQUISA}

Para o autor Gil (2002, p. 17), “a pesquisa é requerida quando não se dispõe de informação suficiente para responder ao problema, ou então quando a informação disponível se encontra em tal estado de desordem que não possa ser adequadamente relacionada ao problema”.

Considerando, no entanto, que a abordagem qualitativa, enquanto exercício de pesquisa, não se apresenta como uma proposta rigidamente estruturada, ela permite que a imaginação e a criatividade levem os investigadores a propor trabalhos que explorem novos enfoques (GODOY, 1995, p. 21).

Estes conceitos colaboraram para o desenvolvimento e estruturação da metodologia desta dissertação, resumida no Quadro 3:

Quadro 3 - Estrutura da metodologia

\begin{tabular}{|c|c|c|c|c|}
\hline Etapas & Tipos da Pesquisa & Objetivos da Pesquisa & Questões da Pesquisa & Levantamento/Análise de Dados \\
\hline $\begin{array}{c}\text { ETAPA } 1 \\
\text { Levantamento } \\
\text { das teorias }\end{array}$ & Pesquisa bibliográfica & $\begin{array}{l}\text { Levantamento das teorias } \\
\text { existentes para a análise dos } \\
\text { resultados }\end{array}$ & & Pesquisa na internet \\
\hline \multirow{2}{*}{$\begin{array}{c}\text { ETAPA } 2 \\
\text { Levantamento } \\
\text { dos problemas } \\
\text { critérios }\end{array}$} & $\begin{array}{l}\text { Entrevista (pré-teste) com } \\
\text { executivo de uma empresa }\end{array}$ & \multirow{2}{*}{$\begin{array}{l}\text { Validar e obter os principais } \\
\text { problemas e critérios de } \\
\text { cuidados em comum para as } \\
\text { empresas entrantes }\end{array}$} & \multirow{2}{*}{$\begin{array}{l}\text { Questões abertas - Relate como foi o } \\
\text { processo decisório de entrada no Brasil e } \\
\text { seus principais desafios? }\end{array}$} & \multirow{2}{*}{ Pesquisa exploratória qualitativa } \\
\hline & $\begin{array}{l}\text { Entrevista com executivos } \\
\text { das outras empresas }\end{array}$ & & & \\
\hline $\begin{array}{c}\text { ETAPA } 3 \\
\text { Levantamento } \\
\text { das entidades } \\
\text { e critérios } \\
\text { relevantes }\end{array}$ & $\begin{array}{l}\text { Entrevista com executivos } \\
\text { das entidades de fomento à } \\
\text { entrada no Brasil }\end{array}$ & $\begin{array}{c}\text { Determinar os critérios não } \\
\text { considerados que poderiam ser } \\
\text { relevantes às empresas } \\
\text { entrantes no Brasil }\end{array}$ & $\begin{array}{l}\text { Questões abertas - Quais critérios são } \\
\text { importantes para o processo de entrada de } \\
\text { uma empresa no Brasil? }\end{array}$ & $\begin{array}{c}\text { Pesquisa na internet e exploratória com } \\
\text { entidades }\end{array}$ \\
\hline $\begin{array}{l}\text { ETAPA } 4 \\
\text { Validação dos } \\
\text { critérios }\end{array}$ & Entrevista com especialistas & $\begin{array}{c}\text { Confirmação dos critérios e } \\
\text { práticas a serem recomendadas } \\
\text { para o processo de empresas } \\
\text { entrantes no Brasil }\end{array}$ & $\begin{array}{l}\text { Questões abertas - Conhecido os problemas } \\
\text { mencionados nesta dissertação e critérios } \\
\text { apontados por entidades de suporte à } \\
\text { entrada de empresas no Brasil, poderia } \\
\text { comentar sua opinião sobre esses critérios } \\
\text { e se existe algo adicional para } \\
\text { complementar? } \\
\end{array}$ & Pesquisa exploratória \\
\hline
\end{tabular}

Fonte: Elaborado pelo autor (2018).

\subsection{Etapa 1 - Pesquisa bibliográfica}

Essa etapa 1 serviu de alicerce para o estudo, conhecimento e definição das teorias existentes e relacionadas ao tema dessa dissertação. Foram pesquisadas diferentes fontes online como 
Google Scholar, Google, biblioteca da Universidade de São Paulo e outras instituições. Nesta etapa de pesquisa, o autor optou por três grupos teóricos por se complementarem e estarem diretamente relacionados entre eles.

O primeiro grupo teórico, chamado de teorias da internacionalização, foi pesquisado, culminando na evolução cronológica de cada teoria. O objetivo foi demonstrar as principais características de cada teoria de internacionalização e os possíveis resultados decorrentes da escolha de cada uma delas nas empresas que as adotaram, segundo seus autores. O segundo grupo foram os modos de entrada existentes e mais comuns às empresas estrangeiras no Brasil. O terceiro e último grupo teórico foram as barreiras à entrada mais comuns enfrentadas por empresas ao ingressarem no Brasil. Esta pesquisa bibliográfica foi iniciada em meados de setembro de 2016 até meados de outubro de 2017.

A escolha do autor em pesquisar os modos de entrada e as barreiras à entrada foi devido à menção, de ambos assuntos, pelos autores e pesquisadores das teorias de internacionalização. A etapa 1 acima juntamente com a etapa 2, deram sustentação para a análise e desdobramento das etapas finais 3 e 4 a seguir.

\subsection{Etapa 2 - Pesquisa exploratória qualitativa}

Essa etapa foi elaborada com o objetivo de levantar e estudar experiências passadas por empresas estrangeiras ao ingressarem no Brasil. Para testar o questionário a ser aplicado nas empresas, o autor criou uma fase chamada de pré-teste.

Foram dois os critérios de escolha da empresa do pré-teste. Primeiro o relacionamento de amizade com o executivo que participou do processo de entrada de sua empresa, e, segundo, pois se tratava de uma empresa do setor industrial, e isso serviu para avaliar se os problemas e barreiras enfrentados não se limitariam às empresas do setor de saúde. O questionário do préteste se encontra no Apêndice A. A entrevista pré-teste foi realizada no mês de fevereiro de 2017. 
Realizada a fase pré-teste, seguiu-se para a fase da pesquisa exploratória com a seleção de quatro empresas. Essas empresas foram escolhidas pelo autor desta dissertação pois ele participou no processo de entrada no Brasil dessas empresas, facilitando o acesso aos executivos entrevistados e análise dos dados. O questionário semiestruturado encontra-se no Apêndice B e foi aplicado via e-mail aos respondentes entre os meses de março a abril de 2017. Por questões de confidencialidade, tanto os nomes das empresas quanto dos entrevistados, foram preservados em sigilo. Essa etapa foi elaborada também com o objetivo de levantar se houve a avaliação e análise de critérios para uma empresa entrar no Brasil.

Quadro 4-Empresas entrevistadas

\begin{tabular}{|c|c|c|c|}
\hline Empresas & Cargo do entrevistado & Setor & Início das atividades \\
\hline Paris & Diretor Comercial & material escolar & 2004 \\
\hline Montreal & Gerente Administrativo & saúde & 2008 \\
\hline Roma & Diretor Administrativo & saúde & 2010 \\
\hline Angrez & Sócio-diretor & software & 2011 \\
\hline
\end{tabular}

Fonte: Elaborado pelo autor (2018).

\subsection{Etapa 3 - Pesquisa com entidades de apoio à internacionalização}

Essa etapa foi desenvolvida com o objetivo de listar os critérios relevantes e as possíveis barreiras encontradas por empresas entrantes que foram atendidas pelas instituições de fomento e apoio à internacionalização, como, as câmaras de comércio, consulados e outras entidades independentes.

Dentre as 68 entidades existentes, segundo a pesquisa on-line, realizada pelo autor, foram contatadas 9, as quais o autor acreditou apresentarem maior representatividade no mercado brasileiro. Outro fator de escolha foi o fato das sedes se encontrarem na cidade de São Paulo, o que poderia ser um facilitador, caso houvesse necessidade de encontro presencial. O Quadro 5 abaixo relaciona as entidades contatadas. Esta fase de entrevistas foi realizada entre os meses de outubro e novembro de 2017. 
Quadro 5 - Entidades de apoio à internacionalização contatadas no Brasil

\begin{tabular}{|l|c|l|}
\hline \multicolumn{1}{|c|}{ Nome } & País de origem & \multicolumn{1}{c|}{ Website } \\
\hline AHK - Câmara de Comércio e Ind. Brasil-Alemanha & Alemanha & www.ahkbrasil.com \\
\hline Câmara Portuguesa & Portugal & www.camaraportuguesa.com.br \\
\hline CCBC - Câmara de Comércio Brasil-Canadá & Canadá & www.ccbc.org.br \\
\hline CCIBC - Câmara Brasil-China & China & www.camarabrasilchina.com.br \\
\hline CCIFB - Câmara de Comércio França-Brasil & França & www.ccfb.com.br \\
\hline ITALCAM - Câmara Ítalo-brasileira & Itália & www.italcam.com.br \\
\hline JETRO - Japan External Trade Organization & Japão & www.jewtro.go.jp/brazil \\
\hline KOTRA - Korea Trade - Investment & Corea do Sul & www.kotrarj.org \\
\hline SWEDCHAM - Câmara Sueco-brasileira & Suécia & www.swedcham.com.br \\
\hline
\end{tabular}

Fonte: Elaborado pelo autor (2018).

A obtenção desta listagem foi resultante de pesquisas na internet, buscando-se com palavraschaves como: "câmaras de comércio no Brasil"; "consulados no Brasil"; "entidades de fomento à internacionalização de empresas estrangeiras"; “consultoria especializada em internacionalização de empresas no Brasil”. Foram levantadas as principais informações como contato, e-mail, telefone e endereço de cada entidade. O primeiro contato foi realizado por telefone para o levantamento da pessoa melhor indicada a receber o questionário, enviado em seguida por e-mail. O questionário utilizado encontra-se no Apêndice C.

\subsection{Etapa 4 - Pesquisa com especialistas no processo de entrada no Brasil}

Esta quarta e última etapa teve como objetivo, validar os critérios mencionados durante as entrevistas com as entidades de apoio a expansão internacional, descritos na etapas 3 .

Para isso, e pela facilidade da rede de contatos do autor desse trabalho, foram escolhidos cinco consultores especialistas em internacionalização de empresas que receberam, via e-mail, o modelo de critérios resultante da etapa 3, e puderam comentar e adicionar outros critérios de cuidados que foram considerados nos achados finais. Todos os cinco consultores responderam a pesquisa e a listagem dos seus nomes, autorizados por eles, se encontra no Apêndice D. Esta etapa foi realizada em março de 2018. 
A partir de todas essas etapas, realizou-se a triangulação da análise dos dados da seguinte maneira: As entrevistas nas empresas, etapa 2, trabalhadas pelo autor, serviram de base para a criação do questionário semiestruturado e aplicado para a realização da etapa 3. O resultado foi enviado aos consultores especialistas que responderam com pontos de cuidados adicionais, incluídos no modelo de processo de ingresso de empresas interessadas no Brasil. Por fim, o autor, baseado nas 3 etapas e em sua vivência profissional, propõe, em modelo de fluxograma, os pontos e cuidados a serem observados por dirigentes de empresas interessadas no mercado brasileiro. 


\section{RESULTADOS}

Esse capítulo descreve os resultados encontrados nas 3 etapas as quais foram realizadas as entrevistas, descrevendo de forma detalhada, como foram realizadas as entrevistas e seus achados, concluindo com a proposição final de critérios colocados pelo autor.

\subsection{Resultados do pré-teste}

Esse subcapítulo demonstra e relata como foi realizado o pré-teste que teve como objetivo, servir de base para o aperfeiçoamento do questionário semiestruturado, utilizado na etapa seguinte.

A entrevista foi realizada por telefone com um executivo expatriado da Suécia, que, à época da entrevista, exercia o cargo de gerente comercial da empresa no Brasil. O nome da empresa foi preservado no anonimato.

\section{Perfil da empresa}

Fabricante de equipamentos para sistemas de óleos vegetais e sistemas de vácuo, a empresa possui 145 anos de existência e 350 funcionários no mundo. Há 30 anos recomeçou a expansão global, focando na Índia, China e Indonésia, e, em 1968, chegaram os primeiros equipamentos ao Brasil.

\section{Modo de entrada}

Desde 2010, a empresa atuava, via representação, por uma empresa brasileira, de maneira que o seu maior foco era o mercado de trocadores de calor. No mesmo ano, essa representante foi adquirida por uma multinacional e, por conseguinte, deixou de atuar com os equipamentos da empresa alemã, diminuindo consideravelmente o volume de vendas. Devido a este fato, e de acordo com relato do entrevistado, decidiu-se pela abertura da filial no Brasil, apenas tendo como base o histórico de vendas. 


\section{Barreias à entrada}

Carga tributária - para auxiliar no desenvolvimento do processo de introdução, a empresa contratou uma grande consultoria renomada no mundo e mesmo assim, segundo o entrevistado, se surpreendeu com a carga tributária e optou por contratar uma equipe gerencial com salário defasado com o mercado. Isso proporcionou descontentamento e dificuldade de incremento de vendas.

Falta de conhecimento do mercado local - Somente após um ano - com a abertura da empresa e com CNPJ pronto para faturamento - foi iniciado o processo de contratação de um gerente comercial para o Brasil com o mesmo problema de salário defasado em relação ao mercado, o que constituiu outro desafio de falha de entendimento da matriz em relação ao mercado e ao custo da remuneração no Brasil.

Barreiras econômicas - ainda em 2013, iniciou-se a expansão com representações na América Latina, porém, dois anos após, devido à crise brasileira, a empresa demitiu um dos vendedores, contabilizando uma perda de $20 \%$ a $30 \%$ do faturamento local.

\section{Critérios sugeridos para a entrada no Brasil}

Para o entrevistado, foi relatado que os critérios abaixo, se foram considerados em algum momento, não foram respeitados ou seguidos:

- Planejamento estratégico;

- Tamanho do mercado vs. retorno desejado;

- Salários estipulados defasados com o momento do mercado;

- Não houve treinamento de vendas;

- Falta de pessoal com conhecimento do setor;

- Matriz não sabe fazer marketing.

Como não houve mudança nos resultados observados na etapa do pré-teste, o autor optou por considerá-los na análise dessa dissertação. 


\subsection{Resultados da pesquisa exploratória: empresas}

Este subcapítulo descreve os resultados encontrados nas pesquisas realizadas com as 4 empresas descritas pelo autor na seção relato da experiência e busca atender um dos objetivos secundários.

De acordo com o questionário semiestruturado que os participantes responderam, os resultados e análises estão apresentados por cada empresa e foram agrupados em 3 grupos: modelo de entrada, barreiras à entrada e critérios a serem observados.

As descrições do perfil das empresas a seguir já foram relatadas no capítulo 4.1, relato da experiência.

\section{1) Empresa "Paris", fabricante de utensílios escolares:}

\section{Modo de entrada}

Segundo relatado na entrevista, a matriz, por possuir uma filial na Argentina, pediu ajuda para encontrar algum parceiro inicial no Brasil. Após algumas visitas do staff argentino, teve a indicação de um escritório de contabilidade no Brasil, que disponibilizou uma sala pequena e endereço físico, além da assessoria de abertura da subsidiária nacional, modo de entrada sugerido por esse escritório. Como mencionado na teoria por Dias, Rocha e Silva (2014), para a empresa que dispõe de capital próprio, o modo escolhido é baseado no nível de propriedade que a empresa terá.

\section{Barreiras à entrada}

Idioma - pela necessidade de agilizar o início das vendas, a apresentação e treinamento dos produtos foram realizados de maneira presencial, entre o especialista francês e os representantes comerciais, com tradução simultânea. Isso levou a déficit de aproveitamento do treinamento e informações relevantes.

Vantagens de custos das empresas locais - o maior concorrente está estruturado no Brasil com boa parte da fabricação local. Isso dificultou a justificativa de apresentar uma nova linha de 
produtos com preço mais alto. Segundo o entrevistado, para entrarem numa rede de distribuição grande, passaram-se alguns meses de negociação e revisão do preço pela matriz até que finalmente conseguiram a conta.

Adaptação de produtos - por se tratar de um produto complementar e mais caro em relação aos concorrentes nacionais, a empresa demorou para ingressar nos mercados mais populares de regiões distantes das grandes capitais brasileiras.

\section{Critérios sugeridos para a entrada no Brasil}

O entrevistado, após a experiência com o Brasil, acredita que se tivesse realizado um estudo prévio de mercado incluindo melhor conhecimento sobre os ambientes econômicos, políticos e sociais, algumas tarefas teriam sido encurtadas e o prazo de ingresso no mercado diminuído. O levantamento dos players, concorrentes principais e formas de atuação, e do custo logístico também são pontos importantes de se antecipar e conhecer.

\section{2) Empresa "Montreal", fabricante de equipamentos médicos:}

\section{Modo de entrada}

Segundo a entrevista, a empresa inicialmente havia traçado um plano de visitar o Brasil para encontrar com potenciais clientes e distribuidores, com o objetivo de iniciar suas atividades por aliança estratégica. Após algumas reuniões e vindas ao Brasil, o diretor concluiu que o modo de entrada mais adequado ao seu perfil e momento da empresa era o da abertura de subsidiária própria. Lembrando que esse modo é uma operação complexa, mais custosa, com máximo controle sobre a operação e retornos esperados acima da média (HITT; IRELAND; HOSKISSON, 2011).

\section{Barreias à entrada}

Idioma - por se tratar de uma empresa no setor da saúde, todo o material técnico e algumas certificações estrangeiras exigidas pelas autoridades eram obrigatoriamente traduzidos para o português. Outro ponto mencionado foi que o diretor da empresa não falava o português, e, por estar envolvido na operação, houve um foco grande para agilizar o domínio do idioma com aulas particulares. 
Mudanças necessárias para atividades promocionais - novamente, por se tratar de uma empresa no ramo da saúde, o entrevistado relata a burocracia e altas demandas na adequação das embalagens e todo o material promocional sugerido ao uso no Brasil. Existem regras importantes a serem observadas, inclusive para a participação em férias e congressos, que diferem dos mercados europeus e norte-americanos.

Estabilidade da taxa de câmbio - na época em que a empresa iniciou no Brasil, o dólar estava com grandes oscilações. Isso foi um fator que dificultou a correta precificação dos produtos, pelo valor agregado unitário, segundo o entrevistado.

Políticas governamentais - o fator mais citado, pois a matriz não contava e desconhecia os longos prazos necessários para a obtenção de registros dos produtos e outras licenças de funcionamento da empresa brasileira.

\section{Critérios sugeridos para a entrada no Brasil}

Para o entrevistado, o primeiro critério que uma empresa deve considerar no Brasil é conhecer e desenvolver um bom network local. Isso levará aos dirigentes a obterem conhecimento de detalhes e uma preparação para o segundo critério mencionado que é a visitação ao país. Segundo ele, o Brasil oferece diferentes feiras e rodadas de negócio para estrangeiros virem e criarem relacionamento. Com esses dois pontos melhor desenvolvidos, o ponto três é a aquisição de uma pesquisa de mercado profissional no setor da empresa. Essa pesquisa precisa envolver não somente fatores mercadológicos, mas também políticos e econômicos do país, além de possíveis barreiras político-governamentais.

\section{3) Empresa "Roma”, fabricante de substâncias injetáveis para exames radiológicos}

\section{Modo de entrada}

O modo de entrada no caso da empresa Roma foi definido pela situação que os produtos já eram comercializados anteriormente por um distribuidor. Neste caso, e também por orientação de um escritório de advocacia, segundo o entrevistado, o modo de entrada escolhido foi a aquisição de uma empresa. O objetivo definido foi obter uma empresa legalmente apta a operar e faturar no Brasil, mesmo sem grandes instalações. O que importava, complementou o entrevistado, era estarem aptos para obterem os registros dos produtos de forma rápida para aproveitar o 
momento que era a quebra de contrato do distribuidor, se tornando o seu maior concorrente. Como mencionado, essa modalidade permite rápido acesso ao novo mercado, custo elevado e negociações complexas (HITT; IRELAND; HOSKISSON, 2011).

\section{Barreiras à entrada}

Acesso a canais de distribuição - apesar da marca ser conhecida e bem aceita no mercado europeu, diferente do que pensaram os dirigentes, esse desafio existiu no Brasil. O distribuidor que importava o produto era a principal concorrente com outros produtos complementares. $\mathrm{O}$ contrato foi encerrado pois este distribuidor passou a trazer o produto de sua própria marca deixando bem limitado o canal de distribuição para a empresa Roma. Outros distribuidores menores apresentaram resistência e dificuldade de introduzirem o produto, pois o concorrente era mais conhecido pelos hospitais e clientes.

Custo de mudanças - Mesmo se tratando de um produto de mesma fórmula, porém com nome distinto, uma vez que passou a ser importado por outra empresa, para o governo, era necessária toda a adequação e lançamento de um novo produto no mercado. Isso requisitou todo um processo novo de registros, traduções, novas embalagens, custando tempo e dinheiro. Outro custo relatado, e não previsto, foi que ao lançarem o próprio produto, se depararam com contratos ainda vigentes e de longo prazo entre grandes clientes e os concorrentes, limitando o faturamento no primeiro ano.

Esperada concorrência local e global - Novamente pode-se classificar a existência dessa barreira facilmente pela empresa Roma, pois, apesar de sua entrada por aquisição, teve que iniciar o processo desde o início, levando tempo para o faturamento, deixando a concorrência blindar seus clientes com contratos a longo prazo e preços atrativos para isso.

\section{Critérios sugeridos para a entrada no Brasil}

Nesta entrevista, foi relatado que a empresa, por atuar no território com um distribuidor robusto e a matriz acreditar que sabia das informações básicas do mercado, não realizou uma pesquisa de mercado. O objetivo de vendas e crescimento foi estipulado sobre as vendas do distribuidor sem levar em consideração a complexidade, desconhecida, segundo relatado, do processo todo. Após os primeiros poucos meses de operação, mostrou-se imprescindível o conhecimento do tamanho do mercado e seus players, principalmente dos hospitais e clientes que estavam em 
poder do distribuidor. Visitas prévias em feiras e contatos com pessoas locais também teriam sido de grande valia, pois muitos dos desafios enfrentados poderiam ser minimizados.

\section{4) Empresa "Angrez", fabricante de software para o mercado da saúde}

\section{Modo de entrada}

O modo de entrada desta empresa, diferente dos outros casos, foi via exportação. O diretor indiano, ao conhecer o executivo em uma feira no Brasil e apresentar o software, o motivou a ser o seu representante exclusivo. Segundo os autores Hitt, Ireland e Hoskisson (2011), o modo por exportação possui alto custo de transporte e pouco controle sobre o mercado anfitrião.

\section{Barreiras à entrada}

Idioma - primeira barreira relatada, pois, se tratando de um software com muitas possibilidades de customização, os treinamentos e adaptações, além de atendimentos aos interessados em conhecer o produto, eram realizados em inglês. Infelizmente, muitos técnicos brasileiros, capazes de avaliarem o produto, não falavam o inglês, e isso retardou e trouxe uma certa desconfiança perante o produto.

Custo de mudanças - como o software aceitava diversas modificações e customizações, os clientes interessados, durante a fase testes, exigiam e estressavam ao máximo a capacidade do software. Isso gerou custos de mão de obra dedicada na Índia, além de diversas visitas e reuniões presenciais no cliente.

Estabilidade da taxa de câmbio - a matriz foi surpreendida com o custo em que o produto chegava ao cliente final. Além disso, a incerteza da taxa de câmbio passava insegurança aos importadores locais repercutindo na matriz em baixar os preços numa tentativa de tornar eles mais competitivos.

Esperada concorrência local e global - a matriz inicialmente acreditou que não houvesse concorrência de mercado ou empresas locais também recentes, com recursos disponíveis para expansão. Rapidamente, outras empresas passarem a apresentar esse mesmo tipo de produto importado, com a diferença de possuírem uma aliança com a matriz, dando subsídios financeiros para suportarem o prazo de maturação dos produtos delas no mercado. 


\section{Critérios sugeridos para a entrada no Brasil}

Para esse dirigente, os principais critérios a serem observados foram o estudo do mercado e players locais. Ele acredita que isso não exclui a surpresa de novos concorrentes entrantes e com maior poder econômico, mas, por outro lado, diminui falsas expectativas dos membros diretivos. Participar de rodadas de negócios também possibilitaria contato com outros parceiros, que, em sua opinião, proporcionariam a obtenção de mais opções de importadores, já que o Brasil é um país muito grande. Ter informações sobre a economia, como impostos e taxa de câmbio no Brasil, possibilitaria a confecção de um plano estratégico, o que não houve, pois não se julgou necessário, se tratando de um modo de entrada de exportação.

\subsection{Resultados da pesquisa com entidades de apoio à internacionalização}

Este subcapítulo busca atender a um dos objetivos secundários, especificamente para identificar e entender as entidades de apoio à internacionalização de empresas no Brasil, se as elas possuem critérios de cuidados para a devida fomentação e melhor garantia do sucesso de ingresso de seus clientes.

Do total de 9 organizações que receberam o questionário semiestruturado, 5 responderam e 4 não responderam, pois usam consultores autônomos ou não puderam responder. A pesquisa teria que focar nesses consultores autônomos, porém, isso fugiria da proposta desta etapa. Das 5 respondentes, 3 são câmaras de comércio e 2 são entidades de fomento à internacionalização que trabalham em paralelo à câmara de comércio do respectivo país.

Quase todas possuem associados que são empresas ou pessoas físicas, que, através de um custo mensal, passam a usufruir de certas vantagens pela associação. Todas possuem estudos e informações sobre o Brasil, disponíveis ao público em geral em seus websites ou bibliotecas físicas nos respectivos escritórios.

Encontrou-se similaridade na forma de atuação dessas entidades no Brasil com as empresas interessadas. Através de pesquisas constantes, as entidades buscam por oportunidades no mercado local que possam atender a sua rede de empresas associadas, já estabelecidas no Brasil, 
e as empresas estrangeiras. Cria-se uma proposta comercial com respectivos custos e tempo de implantação do projeto, que, se aceito, passa para a fase de introdução, dando seguimento ao desenvolvimento e conclusão. A entidade é responsável por todo o processo, atendendo a empresa de forma completa.

Outra forma de processo é quando a entidade aqui no Brasil é contatada pela empresa estrangeira interessada no mercado brasileiro. Este processo é desenvolvido primeiramente com o entendimento do produto ou serviço a ser oferecido, seguido pela apresentação dos fatores econômicos e políticos brasileiros para a empresa, e, uma vez validada a possibilidade de ingresso, cria-se o projeto de negócios com as etapas de busca de parceiros locais, levantamento dos modos de entrada, pesquisa de mercado e outros fatores relevantes para o setor de atuação. Foi relatado também que pelo fato do Brasil possuir alta carga tributária, é comum que as empresas optem pelo modo de exportação ao invés de abrirem uma filial própria. Em caso de interesse de abertura de filial, as entidades também possuem estrutura de apoio, como escritórios físicos e profissionais da área legal e contábil.

Finalmente, observou-se que as entidades pesquisadas possuem um processo a ser seguido para atender as empresas interessadas no Brasil, e esses processos, atendendo aos cuidados e etapas, serão descritos no próximo subcapítulo.

\subsection{Critérios encontrados}

Este subcapítulo, atendendo ao segundo objetivo secundário desta pesquisa, agrupa o resultado das entrevistas realizadas com as empresas entrantes e as entidades de fomento à internacionalização no Brasil.

Destaca-se que, para a etapa pré-teste, não foi considerado no questionário enviado o levantamento de critérios que poderiam ser adotados, porém, o entrevistado mencionou que os problemas enfrentados poderiam ter sido evitados ou minimizados com a adoção de medidas preventivas. Com esta menção, o autor desta dissertação incluiu nos questionários das etapas seguintes a pergunta sobre critérios que poderiam ser adotados às empresas entrantes no Brasil. 
Para as empresas entrevistadas, foram mencionados diferentes critérios de cuidados que os executivos, após a experiência com o Brasil, acreditam ser relevantes para uma próxima experiência. A Tabela 2, abaixo, agrupa todos os critérios e a quantidade de vezes em que foram mencionados.

Tabela 2-Critérios mencionados pelas empresas entrantes no Brasil
\begin{tabular}{|r|c|}
\hline Critérios & $\begin{array}{r}\text { Quantas vezes for am } \\
\text { mencionados }\end{array}$ \\
\hline \hline $\begin{array}{r}\text { Necessidade de pesquisa de } \\
\text { mercado }\end{array}$ & 4 \\
\hline $\begin{array}{r}\text { Conhecimento prévio dos } \\
\text { principais players }\end{array}$ & 3 \\
\hline Conhecimento do custo logístico & 1 \\
\hline Buscar por network local & 1 \\
\hline Participar em rodadas de negócios & 3 \\
\hline $\begin{array}{r}\text { Entender potenciais barreiras } \\
\text { político governamentais }\end{array}$ & 1 \\
\hline Conhecer o ambiente econômico & 1 \\
\hline
\end{tabular}

Fonte: Elaborado pelo autor (2018).

Para as empresas entrevistadas, nota-se que os critérios mencionados são complementares. Ao mencionarem sobre a necessidade de pesquisa de mercado, alguns dos entrevistados consideraram que esse critério já poderia ter atendido a outros critérios, como conhecimento de alguns players locais, através das marcas e participação respectiva no mercado. Outro exemplo que pode ser citado é sobre a necessidade mencionada em entender potenciais barreiras políticogovernamentais. Ao participar de rodadas de negócios com agentes e potenciais clientes locais, esse critério também pode ser conhecido, segundo um dos entrevistados que participou de tais atividades.

Para as entidades de apoio pesquisadas sobre quais critérios são adotados para as empresas entrantes, o primeiro passo é o entendimento dos produtos e serviços a serem oferecidos. Essa etapa, segundo reportado, é o ponto de partida para que a entidade possa focar na busca dos setores específicos com potenciais clientes e parceiros locais para já iniciar melhor entendimento dos cuidados a serem considerados. Outro critério comentado, ainda nesta primeira etapa, é a exposição de informações relevantes sobre o Brasil, como a dificuldade de abrir e fechar uma empresa, sistema de impostos complexo e regulamentações específicas ao setor, para certificar que o cliente esteja ciente e decidido em expandir suas operações. 
Outro critério relatado e unânime foi a necessidade do levantamento do mercado com a apresentação dos players, potenciais compradores e apresentação dos setores políticos, econômico e culturais. Feito isso, as entidades oferecem, numa etapa inicial ou posterior, porém bem recomendada, a participação do empresário estrangeiro em rodadas de negócios que as entidades promovem e organizam. Segundo as respostas recebidas, isso é importante para o contato direto entre a empresa estrangeira com o ambiente Brasil, seus potenciais parceiros e clientes diretos. Os últimos critérios apontados que essas entidades aplicam às empresas interessadas é a apresentação de uma estratégia de expansão com as opções de modo de entrada, custos relacionados, potenciais barreiras e cronograma a ser respeitado, além do trabalho de oferecerem acompanhamento com a supervisão das atividades e prazos estipulados.

A Figura 4, elaborada pelo autor desta dissertação, resume de forma generalizada o fluxo de atendimento das entidades, seguindo-se os critérios que elas próprias consideram relevantes:

Figura 4 - Critérios apresentados pelas entidades no Brasil de fomento à internacionalização

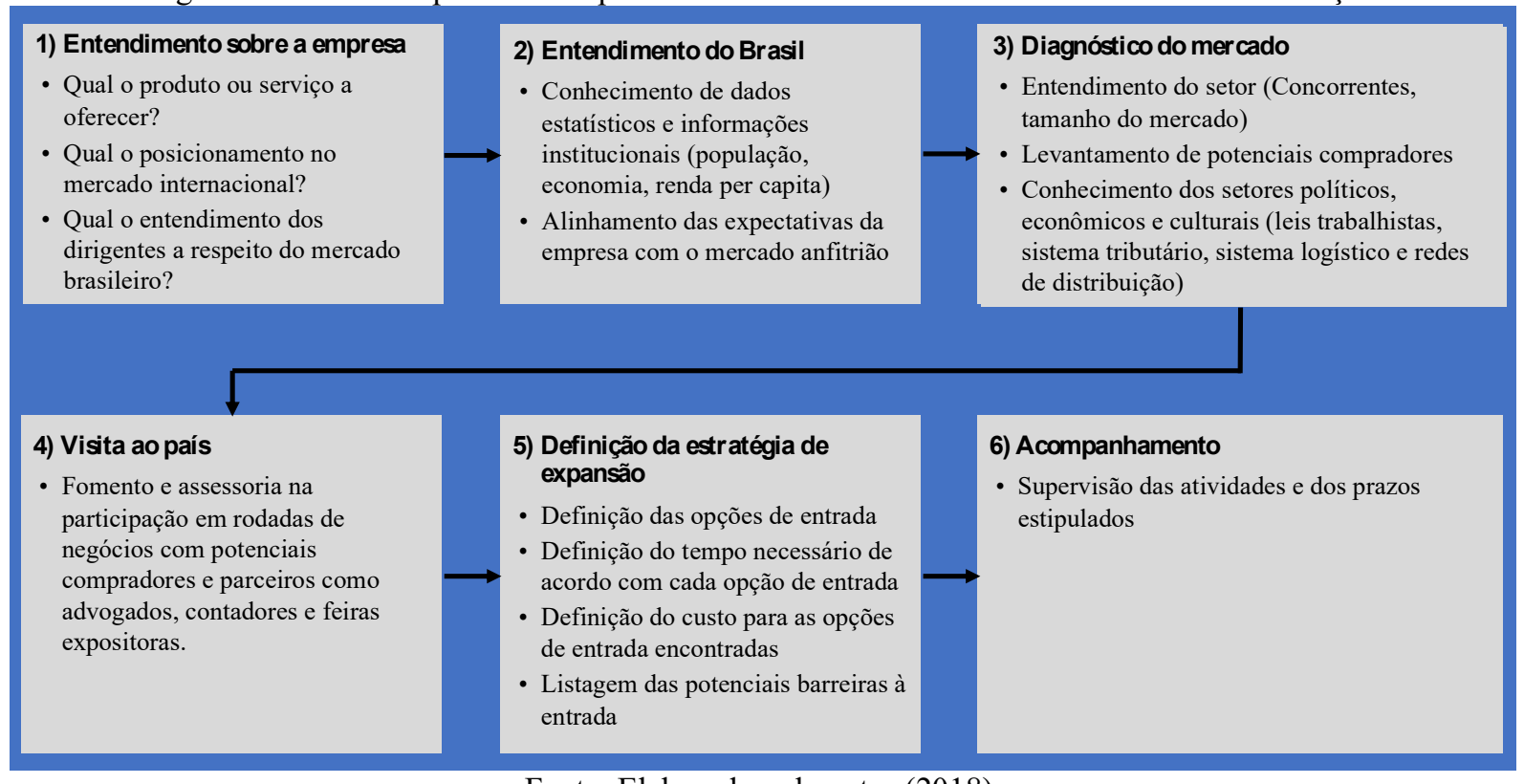

Fonte: Elaborado pelo autor (2018).

Nota-se que as entidades possuem nomes distintos para as etapas mencionadas de critérios, porém o objetivo encontrado em cada etapa foi o mesmo, o que facilitou essa análise e construção desta figura. Algumas das entidades não atuam no ponto 6 de acompanhamento, por esse não fazer parte do escopo de serviço oferecido. 
Essa etapa de levantamento dos critérios com ambos os grupos entrevistados serviu de base de análise para a próxima etapa, na qual especialistas sobre internacionalização complementaram os critérios necessários, como veremos a seguir.

\subsection{Validação dos critérios encontrados}

Para atender ao terceiro objetivo secundário desta dissertação, a etapa de validar os critérios mencionados pelos executivos entrevistados e pelas entidades de suporte às empresas interessadas no mercado brasileiro, foram contatados 5 especialistas no assunto. Esses profissionais são consultores especializados e professores universitários que atuam na área, atendendo e facilitando a entrada dessas empresas. A lista destes especialistas se encontra no Apêndice D.

Os especialistas receberam por e-mail o modelo criado e mencionado acima na Figura 4, para avaliação e validação. Eles puderam editá-lo da forma que melhor acreditassem ser o ideal para uma empresa entrante no Brasil ou considerando sua forma atual de consultoria.

O resultado desses critérios está resumido na Figura 5: 
Figura 5 - Critérios validados pelos especialistas

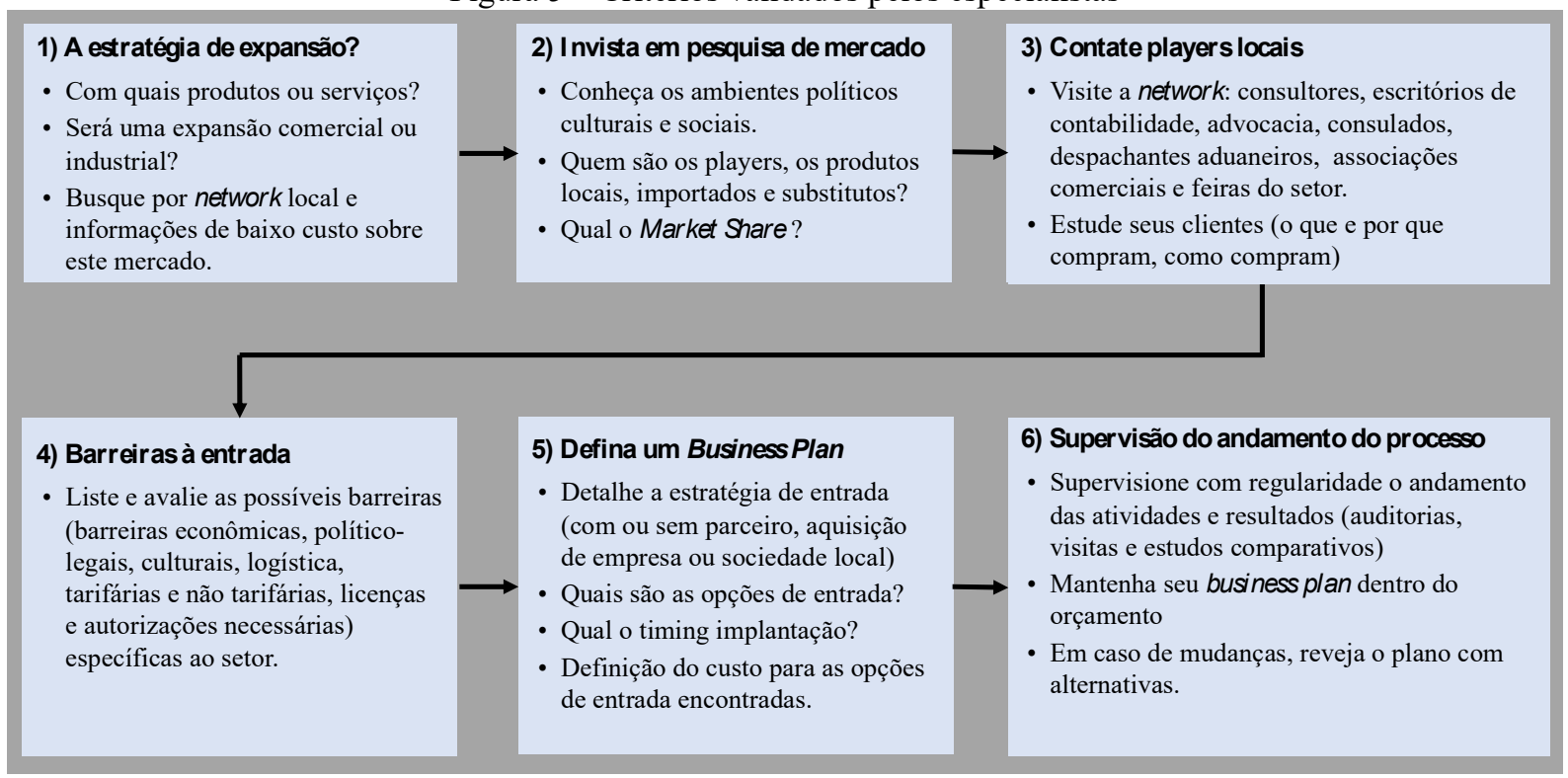

Fonte: Elaborado pelo autor (2018).

Verificou-se que, após a validação, obteve-se um modelo diferente do modelo criado após a entrevista com as entidades de apoio. Os especialistas mencionaram preocupação em apresentar aos seus clientes as barreiras que afetam diretamente o setor enquanto isso foi mencionado pelas entidades, no início da colocação dos critérios, com o objetivo de avaliarem o quanto a empresa está interessada e preparada para enfrentar tais barreiras do mercado brasileiro.

Outra diferença encontrada é as entidades que fomentam às empresas visitarem ao país anfitrião organizando e proporcionando esta atividade, sendo parte fundamental do processo. Os especialistas não mencionaram essa atividade como sendo um critério importante, mas mencionam que realizar contato com players locais ajuda no levantamento de detalhes e outras informações relevantes.

Esse modelo validado serviu para o autor desta dissertação propor o modelo final de critérios, o qual veremos a seguir. 


\subsection{Proposição final de critérios}

Após a revisão e análise dos critérios mencionados pelas empresas entrevistadas, entidades de apoio e especialistas, observa-se a necessidade de uma complementariedade com outros critérios, a fim de melhor explanar e detalhar cuidados a serem tomados na entrada de empresas no Brasil.

Complementar ao resultado visto na prática das entrevistas, pode-se mencionar Deresky (1997), que defende que após a escolha e definição do mercado de expansão, a decisão seguinte - e a mais crítica - é a decisão da melhor forma de entrada neste novo mercado. Os dirigentes precisam entender o modo como sua empresa irá melhor atender às necessidades dos novos mercados potenciais, considerando-se os riscos e outros fatores críticos associados às suas estratégias de entrada.

Para Khanna, Palepu e Sinha (2005), na fase do processo de escolha do território de expansão, é recomendado, de início, realizar uma análise do contexto institucional de cada país, incluindose os seus sistemas políticos e sociais, bem como a receptividade para investimentos estrangeiros e a qualidade de produtos, mão de obra e mercados de capitais existentes nestes países. Uma vez estudados tais fatores, a decisão a ser tomada seria contornar as fraquezas institucionais encontradas, criando uma nova infraestrutura de mercado para o seu negócio, ou então não entrar no país, por entender que adaptar o seu modelo de negócio é impraticável ou economicamente inviável.

Sendo assim, obteve-se o modelo de critérios, resultante da coleta de informações e experiências com as 3 perspectivas que opinaram e colaboraram com o modelo, ou seja, executivos que passaram pela experiência no Brasil, entidades que suportam as empresas de seus respectivos países e os consultores especialistas.

Como já mencionado, segundo as entrevistas, não há obrigatoriedade de seguir os passos numerados. Existem empresas em distintos momentos e status, mais preparadas com informações sobre o mercado, com redes de relacionamentos já desenvolvidas, ou que, até de alguma forma, já atuam com o Brasil através de exportação. O modelo, assim, é sugerido (Fig. 
6) para servir de lista de cuidados e pontos de atenção, ou pode-se chamar de check list de suporte às empresas entrantes no Brasil.

Figura 6 - Proposição final de Critérios

\begin{tabular}{|c|c|}
\hline $\begin{array}{l}\text { 1) Busque por contatos locais } \\
\text { - Pesquise sua network (direta ou indireta) no país de origem; } \\
\text { - Procure saber as informações sobre o mercado com sua } \\
\text { network; } \\
\text { - Utilize associações de fomento ao comércio local; }\end{array}$ & $\begin{array}{l}\text { 2) Conheça o mercado anfitrião } \\
\text { - Invista em pesquisa de mercado (players, produtos locais) } \\
\text { ambientes: Econômico, Político Legal, Cultural e Sistema de } \\
\text { Distribuição) } \\
\text { - Pesquise os concorrentes (Market Share) }\end{array}$ \\
\hline $\begin{array}{l}\text { 3) Visite o país } \\
\text { - Participe em rodadas de negócios; } \\
\text { - Contate potenciais clientes e parceiros como: escritórios de } \\
\text { advocacia, consultorias especializadas no tema, escritórios } \\
\text { contábeis, agentes logísticos, embaixadas, associações } \\
\text { comerciais, agências e bancos de desenvolvimento local; } \\
\text { - Visite feiras do setor no país anfitrião; } \\
\text { - Busque empresas correlatas e representantes comerciais. }\end{array}$ & $\begin{array}{l}\text { 4) Liste as barreiras de entrada } \\
\text { - Barreiras econômicas, político-legais, logísticas, licenças } \\
\text { inerentes ao setor/produtos e barreiras culturais; } \\
\text { - Discuta as barreiras e formas de vencê-las com a network } \\
\text { encontrada. }\end{array}$ \\
\hline $\begin{array}{l}\text { 5) Liste as opções de entrada } \\
\text { - Quais opções de modos de entrada e custos respectivos; } \\
\text { - Realize simulações financeiras em diversos cenários } \\
\text { (considerando os riscos da operação); } \\
\text { - Monte um Business Plan (comercial, jurídico e logístico); } \\
\text { - Prepare-se para adaptar a cultura da empresa para o processo } \\
\text { de internacionalização. }\end{array}$ & $\begin{array}{l}\text { 6) Implementação } \\
\text { - Defina o plano de implementação de acordo com o timing, } \\
\text { recursos disponíveis - pessoal e estrutural e o budget. } \\
\text { 7) Acompanhamento } \\
\text { - Supervisione com regularidade o andamento das atividades e } \\
\text { resultados com visitas e auditorias. }\end{array}$ \\
\hline
\end{tabular}

Fonte: Elaborado pelo autor (2018). 


\section{CONTRIBUIÇÕES FINAIS}

A pesquisa atendeu sua questão de pesquisa, atingiu seu objetivo principal e também contribuiu de forma prática como guia de consulta para executivos e especialistas do tema sobre internacionalização de empresas no Brasil.

Para o seu desenvolvimento, o autor contou com a rede de relacionamento que criou ao longo dos últimos anos, vivenciando o processo de entrada de empresas. Teve-se mais facilidade em revisar as informações que por alguma razão não ficaram bem claras no início e ou precisaram ser reformuladas. Outro ponto que surpreendeu positivamente o autor foi a facilidade e interesse das entidades de apoio existentes aqui no Brasil em colaborarem e dividirem informações sobre o tema. Além disso, não se pode deixar de citar sua percepção do quão estão preparadas e interessadas as pessoas as quais foram consultadas, seja pela parte das entidades como os consultores e professores.

Apesar da situação econômico e político brasileira, no momento em que esta dissertação foi elaborada, não ser favorável para ingresso de empresas, o autor percebeu, no decorrer do desenvolvimento e conversas, que existe um grande potencial para o Brasil ainda a ser explorado com a vinda de novos negócios, e isso é uma das maneiras, inclusive, de ajudar ao desenvolvimento e progresso brasileiro.

Houveram algumas limitações encontradas no decorrer da pesquisa, como, por exemplo, alguma dificuldade em obter-se artigos acadêmicos teóricos que mostrassem empresas estrangeiras com interesse e/ou processo realizado para a vinda ao Brasil. Muito se encontrou de antemão, processos e empresas brasileiras expandindo-se no exterior. Isso não limitou ao aproveitamento de informações e experiências, porém, para o autor, por acreditar e conhecer a especificidade, foi importante o foco em buscar estudos retratando a realidade e processo do mercado brasileiro como anfitrião.

Como sugestão de estudos futuros, o autor acredita ser importante explorar a possibilidade de uma pesquisa mais ampla, com maior amostragem com as empresas entrantes. Isso não foi realizado pois o objetivo era a pesquisa em empresas nas quais o autor havia vivenciado o 
problema proposto. Por outro lado, as entidades de apoio e os serviços prestados pelos especialistas não são limitantes a um setor ou serviço, reforçando, assim, que com maior amostragem de empresas, a validação de critérios pode ser desenvolvida da mesma forma que foi realizada nesta dissertação.

O autor pretende, a partir deste trabalho, desenvolver um manual, em formato de livro, abordando cada um dos pontos críticos para a introdução de empresas no Brasil. O objetivo do livro é facilitar a utilização pelas empresas e seus dirigentes, como um guia prático, indicando os cuidados que deverão ser observados e os riscos eminentes caso não sejam considerados.

Pretende-se para esse trabalho, enriquecer, para cada um dos critérios, novas pesquisas de casos reais e mostrando a ligação com a teoria existente.

Esta dissertação serve de base para estudos futuros, além de guia de consulta e critérios de cuidados a serem avaliados por empresários e consultores de apoio a empresas interessadas em expandirem de forma sólida e estruturada no Brasil. 


\section{REFERÊNCIAS}

AGARWAL, J.; MALHOTRA, N. K.; ULGADO, F. M. Internationalization and Entry Modes: A Multitheoretical Framework and Research Propositions. Journal of International Marketing, v. 11, n. 4, p. 1-31, 2003.

AGARWAL, S.; RAMASWAMI, S. N. Choice of Foreign Market Entry Mode: Impact of Ownership, Location and Internalization Factors. Journal of International Business Studies, v. 23, n. 1, p. 1-27, 1992.

ALMOR, T.; HASHAI, N. The competitive advantage and strategic configuration of knowledge-intensive, small- and medium-sized multinationals: A modified resource-based view. Journal of International Management, v. 10, n. 4, p. 479-500, 2004.

ANDERSEN, O. Internationalization and market entry mode: A review of theories and conceptual frameworks. Management International Review, v. 37, n. 2, p. 27-42, 1997.

ANDERSON, E.; GATIGNON, H. Modes of Foreign Entry: A Transaction Cost Analysis and Propositions. Journal of International Business Studies, v. 17, n. 3, p. 1-26, 1986.

BAIN, J. S. Barriers to new competition: their character and consequences in manufacturing industries. [s.l: s.n.].

BEACH, L. R.; MITCHELL, T. R. A Contingency Model for the Selection of Decision Strategies. The Academy of Management Review, v. 3, n. 3, p. 439-449, 1978.

BLOMSTERMO, A. et al. The perceived usefulness of network experiential knowledge in the internationalizing firm. Journal of International Management, v. 10, n. 3, p. 355-373, 2004.

BUCKLEY, P. J.; CASSON, M. An economic model of international joint venture strategy. Journal of International Business Studies, v. 27, n. 5, p. 849-876, 1996.

. The future of the multinational enterprise - Chapter 3. The future of the multinational enterprise, p. 116, 1976.

The multinational enterprise revisited: The essential Buckley and Casson. [s.l: s.n.].

BUCKLEY, P. J.; CASSON, M. C. Analyzing foreign market entry strategies: Extending the internalization approach. Journal of International Business Studies, v. 29, n. 3, p. 539-561, 1998.

BUCKLEY, P. J.; HASHAI, N. Firm configuration and internationalisation: A model. International Business Review, v. 14, n. 6, p. 655-675, 2005.

BUCKLEY, P. J. Stephen Hymer: Three phases, one approach? International Business

Review, v. 15, n. 2 SPEC. ISS., p. 140-147, 2006. 
CARNEIRO, J.; DIB, L. A. Avaliação comparativa do escopo descritivo e explanatório dos principais modelos de internacionalização de empresas. INTERNEXT - Revista Eletrônica de Negócios Internacionais da ESPM, v. 2, p. 1-25, 2007.

CARPANO, C.; RAHMAN, M.; ROTH, K. Resources, mobility barriers, and the international competitive position of an industry. Journal of International Management, 2003.

CAVES, R. E. International Corporations: The Industrial Economics of Foreign Investment. Economica, v. 38, n. 149, p. 1, 1971.

COASE, R. H. The Nature of the Firm. Economica, v. 4, n. 16, p. 386-405, 1937.

COVIELLO, N. E.; GHAURI, P. N.; MARTIN, K. A.M. International Competitiveness: Empirical Findings from SME Service Firms. Journal of International Marketing, v. 6, n. 2, p. 8-27, 1998.

CUMBERLAND, F. Theory Development within International Market Entry Mode -An Assessment. The Marketing Review, v. 6, p. 349-373, 2006.

CYERT, R. M.; MARCH, J. G. A Behavioral Theory of the Firm. In: A Behavioral Theory of the Firm. [s.l: s.n.]. p. 161-176.

DECKER, R.; ZHAO, X. SMEs' Choice of Foreign Market Entry Mode: A Normative Approach. International Journal of Business and Economics, v. 3, n. 3, p. 181-200, 2004.

DERESKY, H. Formulating StrategyInternational Management: Managing Across Borders and Cultures: Text and Cases, 1997.

DIAS, A. C. A. E. M.; ROCHA, A. M. C. D; SILVA, J. F. D. Modos de Entrada no Investimento Direto no Exterior: Um Estudo da Literatura Empírica. Rac, v. 18, n. 4, p. 416445, 2014.

DUNNING, J. H. The Eclectic Paradigm. London: Palgrave Macmillan UK, 2015.

. The eclectic paradigm as an envelope for economic and business theories of MNE activity. International Business Review, v. 9, n. 2, p. 163-190, 2000.

. Toward an Eclectic Theory of International Production: Some Empirical Tests.

Journal of International Business Studies, v. 11, n. 1, p. 9-31, 1980.

Trade, Location of Economic Activity and the MNE: A Search for an Eclectic Approach. In: The International Allocation of Economic Activity: Proceedings of Nobel Symposium Held at Stockholm. [s.l: s.n.]. p. 395-418.

When I met Hymer: Some personal recollections. International Business Review, v. 15, n. 2 SPEC. ISS., p. 115-123, 2006. 
EKELEDO, I.; SIVAKUMAR, K. Foreign market entry mode choice of service firms: A contingency perspective. Academy of Marketing Science, v. 26, n. 4, p. 274-292, 1998. EKELEDO, I.; SIVAKUMAR, K. International market entry mode strategies of manufacturing firms and service firms. International Marketing Review, v. 21, n. 1, p. $68-$ 101, 2004.

ELG, U.; GHAURI, P. N.; TARNOVSKAYA, V. The role of networks and matching in market entry to emerging retail markets. International Marketing Review, v. 25, n. 6, p. 674-699, 2008.

ELLIS, P. D. Social ties and international entrepreneurship: Opportunities and constraints affecting firm internationalization. Journal of International Business Studies, v. 42, n. 1, p. 99-127, 2011.

ERRAMILLI, M. K.; SHARMA, V. M. Resource-Based Explanation of Entry Mode Choice. Journal of Marketing Theory and Practice, v. 12, n. 1, p. 1-18, 2004.

FIEDLER, F. E. A Theory of Leadership Effectiveness. Journal of Management, v. 17, n. 2, p. 501-503, 1967.

FISCH, J. H. Internalization and internationalization under competing real options. Journal of International Management, v. 14, n. 2, p. 108-123, 2008.

GALBREATH, J.; GALVIN, P. Firm factors, industry structure and performance variation: New empirical evidence to a classic debate. Journal of Business Research, v. 61, n. 2, p. 109-117, 2008.

GAO, T. The Contingency Framework of Foreign Entry Mode Decisions: Locating and Reinforcing the Weakest Link. Multinational Business Review, v. 12, n. 1, p. 37-68, 2004.

GIL, A. C. Como elaborar projeto de pesquisa. São Paulo: Atlas, 2002.

GODOY, A. S. Pesquisa Qualitativa: tipos fundamentais. Revista de Administração de Empresas, v. 35, n. 3, p. 20-29, 1995.

HÅKANSSON, H. Industrial technology development: A network approach: edited by Håkan Håkansson. Journal of Product Innovation Management, v. 4, n. 2, p. 163-165, 1987.

HILAL, A.; HEMAIS, C. A. O Processo de Internacionalização Na Ótica da Escola Nórdica: Evidências Empíricas em Empresas Brasileiras. Revista de Administração Contemporânea, 2003 .

HILL, C. W. L. International Business: Competing in the Global Marketplace, 2013.

HIRSCH, S. An International Trade and Investment Theory of the Firm. Oxford Economic Papers, v. 28, n. 2, p. 258-270, 1976.

HITT, M. A.; IRELAND, R. D.; HOSKISSON, R. E. Administração Estratégica. 2. ed. 2011. 
HYMER, S. H. The International Operations of National Firms: A Study of Direct Foreign Investment. Unpublished PhD Dissertation, MIT Press: Cambridge, MA, 1960. The International Operations of National Firms. 1976.

ISHIKAWA, K. Controle de Qualidade Total: à maneira japonesa. Rio de Janeiro: Campus, 1993.

JEANNET, J.; HENNESSEY, H. D. Global Marketing Strategies. 6. ed. Boston: Houghton Mifflin, 2004.

JOHANSON, J.; VAHLNE, J. E. The Internationalization Process of the Firm - A Model of Knowledge Development and Increasing Foreign Market Commitments. Journal of International Business Studies, v. 8, n. 1, p. 23-32, 1977.

JOHANSON, J.; VAHLNE, J. E. The Uppsala internationalization process model revisited: From liability of foreignness to liability of outsidership. Journal of International Business Studies, v. 40, n. 9, p. 1411-1431, 2009.

JOHANSON, J.; WIEDERSHEIM-PAUL, F. The Internationalization of the Firm - Four Swedish Cases. Journal of Management Studies, v. 12, n. 3, p. 305-323, 1975.

KARAKAYA, F. Barriers to Entry in International Markets. Journal of Global Marketing, v. 7, n. 1, p. 7-24, 1993.

KARAKAYA, F.; STAHL, M. J. Barriers to Entry and Market Entry Decisions in Consumer and Industrial Goods Markets. Journal of Marketing, v. 53, n. 2, p. 80, 1989.

KHANNA, T.; PALEPU, K. G.; SINHA, J. Strategies that fit emerging markets. Harvard Business Review, 2005.

KOTABE, M.; HELSEN, K. Administração de Marketing Global. São Paulo: Atlas, 2000.

KOTLER, P. Megamarketing. Harvard Business Review, v. 64, p. 117-124, 1986.

KUMAR, V.; SUBRAMANIAM, V. A contingency framework for the mode of entry decision. Journal of World Business, v. 32, n. 1, p. 53-72, 1997.

MELIN, L. Internationalization as a strategy process. Strategic Management Journal, v. 13, n. 2 S, p. 99-118, 1992.

OKOROAFO, S. C. Modes of entering foreign markets. Industrial Marketing Management, v. 20, n. 4, p. 341-346, 1991.

OSLAND, G. E.; TAYLOR, C. R.; ZOU, S. Marketing Intelligence \& Planning Emerald Article: Selecting international modes of entry and expansion Selecting international modes of entry and expansion. Market Intelligence \& Planning, v. 19, p. 153-161, 2001. 
PEARCE, R.; PAPANASTASSIOU, M. To "almost see the world": Hierarchy and strategy in Hymer's view of the multinational. International Business Review, v. 15, n. 2 SPEC. ISS., p. 151-165, 2006.

PENROSE, E. Theory of the growth of the firm. Oxford: Basil Blackwell. 1959.

PITELIS, C. Stephen Herbert Hymer and/on the (theory of the) MNE and international business. International Business Review, v. 15, n. 2 SPEC. ISS., p. 103-110, 2006.

PORTER, M. E. Competitive strategy. 1980.

RUNDH, B. International market development: new patterns in SMEs international market behaviour? Management Decision, v. 53, n. 6, p. 319-329, 2001.

RUTASHOBYA, L.; JAENSSON, J. Small firms' internationalization for development in Tanzania. International Journal of Social Economics, v. 31, n. 1/2, p. 159-172, 2004.

SAKARYA, S.; ECKMAN, M.; HYLLEGARD, K. H. Market selection for international expansion. [s.l: s.n.]. v. 24.

SALMI, A. Entry into turbulent business networks - The case of a Western company on the Estonian market. European Journal of Marketing, v. 34, n. 11/12, p. 1374-1390, 2000.

SHARMA, D. D.; BLOMSTERMO, A. The internationalization process of Born Globals: A network view. International Business Review, 2003.

VERNON, R. International Investment and International Trade in the Product Life Cycle. Quarterly Journal of Economics, v. 80, n. 2, p. 190-207, 1966.

WERNERFELT, B. A resource-based view of the firm. Strategic Management Journal, v. 5, n. 2, p. 171-180, 1984.

WHITELOCK, J. Theories of internationalisation and their impact on market entry: University of Warwick eResources. International Marketing Review, v. 19, n. 4, 2002.

WILLIAMSON, O. Markets and hierarchies. New York, p. 26-30, 1975.

WOODCOCK, C. P.; BEAMISH, P. W.; MAKINO, S. Ownership-Based Entry Mode Strategies and International Performance. Journal of International Business Studies, v. 25, n. 2, p. 253-273, 1994.

WORLD BANK GROUP. Doing business 2018. CESifo Forum, v. 15, n. 1, p. 312, 2017.

ZAHEER, S. Overcoming the liability of foreignness. Academy of Management Journal, v. 38, n. 2, p. 341-363, 1995. 
APÊNDICE A - Roteiro - pré-teste

\section{Bem-vindo(a) à Pesquisa Acadêmica}

Obrigado por colaborar voluntariamente como respondente deste questionário. Suas respostas serão mantidas em sigilo e são muito importantes para a sequência do trabalho de pesquisa acadêmica.

Como antecipado por telefone, este trabalho é parte integrante da Dissertação de desenvolvimento do aluno Fabricio Zanella De Bortoli, sob a orientação do Prof. Dr. Martinho Isnard Ribeiro de Almeida, para a conclusão do curso de Mestrado Profissional em Empreendedorismo, da Faculdade de Economia, Administração e Contabilidade (FEA) da Universidade de São Paulo (USP).

A pesquisa dá foco a entender como foi o processo de entrada da empresa no Brasil e suas principais barreiras à entrada encontradas nos primeiros 3 anos.

A pesquisa tem duração média de 15 minutos e estou no aguardo para agendarmos o melhor dia e hora para realizarmos uma nova chamada e, assim, realizarmos a entrevista. Se preferir, estou à disposição para realização da entrevista pessoalmente. Caso queira antecipar dúvidas, estarei à disposição pelo celular (11 99850 8985), pelo mesmo número no aplicativo WhatsApp, ou ainda pelo e-mail fdebortoli@usp.br

Agradeço a sua participação.

Atenciosamente,

Fabricio De Bortoli

Data:

Empresa entrevistada:

Setor de atividade:

Nome do entrevistado:

Cargo na empresa:

País de origem da empresa:

Número de funcionários no mundo:

\section{Modelo de entrada}


1. Como foi definido o processo de entrada no Brasil? Poderia relatar os principais motivos?

\section{Barreiras à entrada}

2. Quais foram as primeiras barreiras à entrada no mercado brasileiro?

3. Em sua opinião, quais critérios você teria sugerido (mesmo se sugeriu, citar) que a sua empresas deveria ter considerado para esse processo de entrada no Brasil? 
APÊNDICE B - Roteiro empresas entrantes

\section{Bem-vindo(a) à Pesquisa Acadêmica}

Obrigado por colaborar voluntariamente como respondente deste questionário. $\underline{\text { Suas }}$

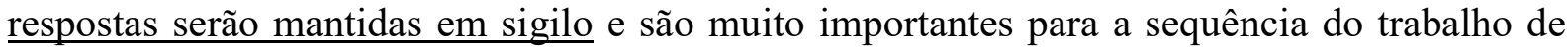
pesquisa acadêmica.

Como antecipado por telefone, este trabalho é parte integrante da Dissertação de desenvolvimento do aluno Fabricio Zanella De Bortoli, sob a orientação do Prof. Dr. Martinho Isnard Ribeiro de Almeida, para a conclusão do curso de Mestrado Profissional em Empreendedorismo, da Faculdade de Economia, Administração e Contabilidade (FEA) da Universidade de São Paulo (USP).

A pesquisa dá foco a entender como foi o processo de entrada da empresa no Brasil e suas principais barreiras à entrada encontradas nos primeiros 3 anos.

A pesquisa tem duração média de 15 minutos e estou no aguardo para agendarmos o melhor dia e hora para realizarmos uma nova chamada e assim realizarmos a entrevista. Se preferir, estou à disposição para realização da entrevista pessoalmente. Caso queira antecipar dúvidas, estarei à disposição pelo celular (11 99850 8985), pelo mesmo número no aplicativo WhatsApp, ou ainda pelo e-mail fdebortoli@usp.br

Agradeço a sua participação.

Atenciosamente,

Fabricio De Bortoli

Data:

Empresa entrevistada:

Setor de atividade:

Nome do entrevistado:

Cargo na empresa:

País de origem da empresa:

Número de funcionários no mundo:

Número de funcionários no Brasil: 


\section{Modelo de entrada}

1 Poderia relatar o que motivou a sua empresa a vir para o Brasil? Já existia alguma relação comercial com o Brasil?

2 Quando e como foi definido o modelo de entrada no mercado brasileiro?

\section{Barreiras à entrada}

3 Quais foram as primeiras barreiras à entrada no mercado brasileiro?

4 Poderia explicar como essas barreiras influenciaram na empresa e sua entrada no mercado?

\section{Critérios}

5 Quais critérios, na sua opinião, as empresas entrantes no Brasil deveriam considerar? 
APÊNDICE C - Roteiro entidades especialistas

\section{Bem-vindo(a) à Pesquisa Acadêmica}

Obrigado por colaborar voluntariamente como respondente deste questionário. Suas respostas serão mantidas em sigilo e são muito importantes para a sequência do trabalho de pesquisa acadêmica.

Este trabalho é parte integrante da Dissertação de desenvolvimento do aluno Fabricio Zanella De Bortoli, sob a orientação do Prof. Dr. Martinho Isnard Ribeiro de Almeida, para a conclusão do curso de Mestrado Profissional em Empreendedorismo, da Faculdade de Economia, Administração e Contabilidade (FEA) da Universidade de São Paulo (USP).

A pesquisa dá foco a entender quais processos são utilizados por instituições de fomento à internacionalização de empresas estrangeiras e quais os critérios devem ser considerados para melhor otimizar e minimizar riscos durante o processo de entrada.

A pesquisa tem duração média de 15 minutos e, em caso de dúvidas, estarei à disposição pelo celular (11 99850 8985), pelo mesmo número no aplicativo WhatsApp, ou, ainda, pelo email fdebortoli@usp.br

Agradeço a sua participação.

Atenciosamente,

Fabricio De Bortoli

\section{1) Tipo de serviço prestado:}

Poderia relatar como ocorre o processo de assessoria às empresas estrangeiras, desde as primeiras orientações até ao apoio específico às estratégias de posicionamento e consolidação das empresas? Poderia citar exemplos que tiveram de empresas (não mencionar nomes)?

2) Critérios para a entrada: (Complementa a pergunta 1) 
Existe um modelo padrão de atendimento para o fluxo de informações ao qual o consultor usa para atender essas empresas, ou seja, quais critérios são usados para melhor avaliar e desenvolver o processo de internacionalização dessas empresas no Brasil? Poderia citar exemplos que tiveram de empresas (não mencionar nomes)?

\section{3) Modos de entrada:}

São diversos os modos de entrada utilizados, porém poderia listar por ordem de menos usado $(=1)$ a mais usado $(=5)$, na lista abaixo:
a. Exportação
b. Licenciamento
c. Alianças estratégicas
d. Aquisição
e. Abertura de subsidiária

Poderia citar alguns exemplos que tiveram.

\section{4) Modos de entrada (motivo):}

Poderia descrever por que indicou, na pergunta anterior, o modo mais indicado e o modo menos indicado?

Poderia citar exemplos que tiveram de empresas (não mencionar nomes)?

\section{5) Barreiras à entrada}

Poderia relatar quais as barreiras à entrada mais encontradas por empresas estrangeiras que a instituição atendeu?

Poderia citar exemplos que tiveram de empresas (não mencionar nomes)? 
APÊNDICE D - Lista de especialistas brasileiros em internacionalização

\section{Fabrizio Broggini}

Fundador e CEO da Broggini Partner in Globalization, se ocupa da estratégia, marketing e organização de médias empresas. Possui ampla experiência com desenvolvimento de análises de mercado e de estratégias de entrada de empresas nos mercados estrangeiros.

E-mail: fabrizio@broggini.com

Site: www.broggini.com

\section{Prof. Felipe Mendes Borini}

Professor de Estratégia Global. Especialidade em Negócios Internacionais. E-mail: fborini@usp.br

\section{Prof. Francisca Grostein}

Mestre em Administração de Empresas pela Universidade Presbiteriana Mackenzie com experiência profissional e acadêmica em Comércio Internacional.

E-mail: grostein@psi.com.br

\section{Igor Tasic}

Conselheiro de empresas, fundador e CEO da Startup Europe Week e membro do European Digital Leaders, do Fórum Econômico Mundial. PhD candidate na UPCT e MSc. na Columbia/FGV-EAESP.

E-mail: igor@startupeuropeweek.eu

\section{Marcelo Basile de Moraes Leme}

Sócio da Moraes Leme Consultoria. Atua desde 1996 em consultoria jurídica e governança corporativa/compliance em projetos internacionais assessorando multinacionais que queiram expandir seus negócios.

E-mail: marceloleme@moraesleme.com.br

Site: www.moraesleme.com.br 